\title{
Królewski dokument rozejmu ze Świdrygiełłą z 20 VIII 1431 roku*
}

\begin{abstract}
Zarys treści: Głównym celem niniejszego artykułu jest publikacja niewydanego dotąd w pełnym tekście dokumentu wystawionego przez króla Władysława Jagiełłę w sprawie rozejmu z wielkim księciem litewskim Świdrygiełłą, zawartego pod Łuckiem 20 VIII 1431 r. Dokument został przekazany stronie litewskiej, w XVII w. padł łupem wojsk rosyjskich i dziś przechowywany jest w Moskwie. Szczególna uwaga poświęcona została gwarantom rozejmów z 20 i 26 VIII 1431 r., wśród których przeważali możni z Wielkopolski.
\end{abstract}

Content outline: The main purpose of this paper is to publish the document, so far unedited in its entirety, issued by Władysław Jagiełło and proclaiming the armistice with Švitrigaila, Grand Duke of Lithuania, near Łuck on 20 August 1431. The document presented to the Lithuanian side, was seized by the Russian army in mid- $17^{\text {th }}$ century and is now housed in an archive in Moscow. A special attention is paid to the guarantors of the truces of 20 and 26 August 1431, the majority among whom were barons of Great Poland.

Słowa kluczowe: Władysław Jagiełło, Litwa, Świdrygiełło, dyplomacja

Keywords: Władysław Jagiełł, Lithuania, Švitrigaila, diplomacy

Niezwykle istotny okres historii Wielkiego Księstwa Litewskiego, jakim były lata trzydzieste XV wieku, możemy poznać bardzo dobrze. Dzięki burzliwym wydarzeniom po śmierci Witolda (przede wszystkim konfliktowi z Polską i wojnie domowej w latach 1432-1438, w których brali udział też sąsiedzi Litwy), powstało sporo źródeł, których znaczna część zachowała się po dziś dzień. Problem jednak polega na tym, że źródła te w znacznym stopniu pozostają niewydane. Mniej lub więcej systematyczne edycje źródłowe, poświęcone specjalnie historii Wielkiego Księstwa, urywają się

* Niniejszy tekst powstał w ramach projektu NCN UMO-2013/11/B/HS3/01462 pt. Dokumenty pokoju brzeskiego z 31 XII 1435 r. między Polską, Litwą a Zakonem Krzyżackim - edycja krytyczna. Autorzy składają serdeczne podziękowania pracownikom Rosyjskiego Archiwum Państwowego Akt Dawnych: zastępcy dyrektora Jurijowi M. Eskinowi, kustoszowi Wadimowi A. Kadikowi i Konstantinowi W. Baranowowi za możliwość korzystania z prezentowanego dokumentu, sporządzenia jego kopii i ogłoszenia drukiem, a także Aleksandrowi W. Baranowowi i Kęstutisowi Gudmantasowi za przesłanie danych o dziewiętnastowiecznych tłumaczeniach i streszczeniach dokumentu przechowywanych w Petersburgu i Wilnie. Gorące podziękowania kierujemy również do prof. UMK dr. hab. Adama Szwedy za życzliwe konsultacje dotyczące odczytu publikowanego tu dokumentu. 
wraz ze śmiercią Witolda ${ }^{1}$. Historycy są więc skazani na korzystanie z wydawnictw źródłowych poświęconych zupełnie innej tematyce ${ }^{2}$. Projekty przygotowania Kodeksu dyplomatycznego Litwy, w znacznej mierze poświęconego źródłom z lat trzydziestych XV w., którym w czasach międzywojennych planowali zająć się Jan Adamus i Oskar Halecki $^{3}$, nie doszły do skutku. Liczne edycje poszczególnych dokumentów i listów wypełniają tę lukę jedynie w nieznacznym stopniu. Pilnym postulatem badawczym pozostaje przygotowanie kodeksu dyplomatycznego obejmującego lata panowania Świdrygiełly i Zygmunta Kiejstutowicza ${ }^{4}$.

Celem niniejszej publikacji jest wprowadzenie do obiegu naukowego pełnego tekstu wystawionego przez króla polskiego Władysława Jagiełłę 20 VIII 1431 r. dokumentu w sprawie zawieszenia broni podczas walk pod Łuckiem. Jest to pierwszy z dokumentów rozejmowych, które doprowadziły do zakończenia polsko-litewskiej wojny na Wołyniu, prowadzonej latem 1431 r. Warunki drugiego z rozejmów, który doprowadził do ostatecznego zawieszenia działań zbrojnych, zostały uzgodnione 26 VIII, a dokument strony polskiej sigillowano 2 IX 1431 r. (o szczegółach działań zbrojnych oraz negocjacji rozejmowych będzie mowa niżej). Jedynie jego tekst (choć zachowany wyłącznie w niemieckim tłumaczeniu) został wydany drukiem w całości lub w postaci obszernych streszczeń ${ }^{5}$.

${ }^{1}$ Codex epistolaris Vitoldi, magni ducis Lithuaniae 1376-1430, wyd. A. Prochaska, Kraków 1882; Vitoldiana. Codex privilegiorum Vitoldi magni ducis Lithuaniae 1386-1430, wyd. J. Ochmański, Warszawa-Poznań 1986. Warto jednak zaznaczyć, że i te edycje nie obejmują wszystkich dokumentów i listów dotyczących historii Wielkiego Księstwa Litewskiego od końca XIV w. do 1430 r.

2 Liv-, est- und kurländisches Urkundenbuch, Abt. I, t. VIII-IX, wyd. H. Hildebrand, Riga-Moskau 1884-1889; Die Berichte der Generalprokuratoren des Deutschen Ordens an der Kurie, t. IV, cz. 1-2, wyd. K. Forstreuter, Göttingen 1973-1976.

3 J. A d a m u s, W sprawie kodeksu dyplomatycznego Litwy, Sprawozdania Towarzystwa Naukowego we Lwowie 12, 1932, z. 3, s. 159-162; te n ż e, Kodeks dyplomatyczny Litwy, Ateneum Wileńskie 8, 1931-1932, s. 428-435; t e n ż e, Wydawnictwa źródeł do historii Litwy, w: Pamiętnik VI Powszechnego Zjazdu Historyków Polskich w Wilnie 17-20 września 1935 r., t. I, Lwów 1935, s. 439-449; W. S e m k o w i c z, Koreferat, w: tamże, t. II, Lwów 1936, s. 196-202.

4 Wiele niepublikowanych dotąd źródeł do dziejów Wielkiego Księstwa Litewskiego w latach trzydziestych XV w. udało się zebrać w trakcie przygotowania książki opartej na rozprawie doktorskiej: С. В. По лех о в, Наследники Витовта. Династическая война в Великом княжестве Литовском в 30-е годы XV века, Москва 2015.

5 Berlin-Dahlem, Geheimes Staatsarchiv Preussischer Kulturbesitz (dalej cyt.: GSPK), XX. HA, Ordensbriefarchiv (dalej cyt.: OBA), nr 5750; Ordensfolianten (dalej cyt.: OF) 14, s. 637643; przestarzała pełna edycja: A. v o n K otz e bu e, Preussens aeltere Geschichte, t. III, Riga 1808, s. 477-483, została oparta na kopii z OBA nr 5750 (m.in. brak drugiej datacji po liście gwarantów), natomiast T. N a r b u t t, Dzieje starożytne narodu litewskiego, t. VII, Wilno 1840, dodatek, s. 23-38, swą pełną edycję oparł na OF 14, podobnie jak I. D a n iło w i c z, Skarbiec diplomatów papieskich, cesarskich, królewskich, książęcych, uchwał narodowych, postanowień różnych władz i urzędów posługujących do krytycznego wyjaśnienia dziejów Litwy, Rusi Litewskiej i ościennych im krajów, t. II, wyd. J. Sidorowicz, Wilno 1862, nr 1562, swoje obszerne streszczenie (z listą gwarantów); co ciekawe T. N a r b u t t, Dzieje starożytne narodu litewskiego, t. VII, s. 38, podał informację, że jeszcze w jego czasach istniała kopia łacińska dokumentu ostatecznego rozejmu z 26 VIII (2 IX) znajdująca się w „Tajn. Arch. Królewieckiém, w Foliancie C. p. 310”, „z której to thumaczenie w języku niemieckim wzięte”; 
Tymczasem zachowany $\mathrm{w}$ oryginale dokument rozejmowy polskiego króla z 20 VIII 1431 r. nigdy jeszcze nie został opublikowany w całości, co powoduje to, że jest on bardzo słabo znany badaczom. Zainteresowanie nim dziewiętnastowiecznych historyków i archiwistów rosyjskich, które znalazło wprawdzie odbicie w odpisach i tłumaczeniach dość wcześnie (co było spowodowane pracami nad edycją dokumentów o stosunkach Rosji z innymi państwami), nie zaowocowało jego publikacją. Interesujący nas dokument miał wspomnianą publikację źródłową otwierać jako najwcześniejszy. Plan ten, który powstał jeszcze w 1810 r., został przerwany wojną z Napoleonem i ewakuacją archiwum z Moskwy w 1812 r. ${ }^{6} \mathrm{Nie}$ doszło również do jego finalizacji później, pomimo prób podjętych w 1. 1813-18147 . Zabrakło specjalistów od języków obcych albo stawiane przez nich warunki finansowe okazały się nie do przyjęcia. W związku z tym kanclerz Nikołaj Rumiancew i jego współpracownicy, którzy wystąpili pierwotnie z tą inicjatywą, skupili się na edycji dokumentów dotyczących stosunków wewnętrznych. Warto przypomnieć, że dzieje Wielkiego Księstwa Litewskiego nie były jeszcze wtedy rozpatrywane jako część historii Rosji i pozostawały dość słabo rozpoznane, dlatego nie powinno dziwić, że dokument ten nie został wówczas opublikowany przez uczonych rosyjskich. Nadzwyczaj lakoniczne wzmianki o nim znajdziemy jedynie w starszych i nowszych przewodnikach po archiwach moskiewskich oraz w „Skarbcu diplomatów” Ignacego Daniłowicza ${ }^{8}$, skąd informację o nim przejął Anatol Lewicki do swego Indeksu aktów

szerzej o rękopisach i edycjach tego źródła zob. Die Staatsverträge des Deutschen Ordens in Preussen im 15 Jahrhundert, t. I, wyd. E. Weise, wyd. 2, Marburg 1970, nr 173.

${ }_{6}$ Materiały Moskiewskiego Archiwum Kolegium Spraw Zagranicznych wróciły do Moskwy 25 I 1813 r., a następnie je uporządkowano (С. А. Б е л о ку р о в, Московский архив Министерства иностранных дел в 1812 году, Москва 1913, s. 48-58).

7 Szerzej zob. Собрание государственных грамот и договоров, ч. V, Москва 1894, s. V-XLVI. Zachowany odpis i tłumaczenie zostały prawdopodobnie sporządzone przez Nikołaja Bantysza-Kamienskiego, w celu przesłania do kanclerza Nikołaja Rumiancewa, co nastąpiło 25 VIII 1813 r. Wypada zwrócić uwagę, że rejestr oryginalnych dokumentów dyplomatycznych zestawiony przez Bantysza-Kamienskiego, który otwiera wydawany dokument, ma datę 23 VI 1813 - Отдел рукописей Российской государственной библиотеки, Ф. 68 (Генеральный штаб), Ед. хр. 301: Реестр договорам и грамотам европейских и азиатских дворов (1431-1724), Л. 1, natomiast thumaczenie tego dokumentu - 8 VIII 1813 r. - Российский государственный архив древних актов, Москва (dalej сyt.: RGADA), Ф. 79, Оп. 3, Ед. хр. 1, Л. 9 об.). Na związek wspomnianego rejestru z przygotowaniem drugiej części Собрания государственных грамот и договоров, dotyczącej stosunków Rosji z innymi państwami, wskazuje także liczba 730 dokumentów; występuje ona również w korespondencji Bantysza-Kamienskiego z Rumiancewem z 1813 r. - Отдел рукописей Российской государственной библиотеки, Ф. 255 (Архив Румянцевых), Карт. 15, Ед. хр. 19, 20.

8 I. D a niłowicz, Skarbiec diplomatów, t. II, nr 1561. Nie wiadomo, w jaki sposób I. Daniłowicz dowiedział się o treści królewskiego dokumentu, podczas podróży do Moskwy w 1818 r. nie pracował już bowiem w Moskiewskim Archiwum Kolegium Spraw Zagranicznych (zob. sprawozdanie z tej podróży: I. Š e n a vi č i e n ė, Ignoto Danilavičiaus raportas apie kelionę ị Maskvą ir Peterburgą (1818 m.), Lietuvos istorijos metraštis 1998, s. 187-205); zapewne zapoznał się z nim podczas służby w Moskwie po 1838 r., możliwe, że przyczynił się do tego książę Michaił Oboleński (1806-1873), który od 1833 służył w moskiewskim archiwum Ministerstwa Spraw Zagranicznych, od 1839 był jego zarządcą, a od 1868 r. dyrektorem; wraz z Daniłowiczem i innymi badaczami wydał w 1843 r. dwie księgi Metryki 
$\mathrm{XV}$ wieku' . Na podstawie tych przekazów dokument był dotąd wykorzystywany w historiografii, np. przy rekonstrukcji itinerarium Władysława Jagiełły ${ }^{10}$.

Pełny tekst dokumentu Władysława Jagiełły z 20 VIII 1431 r. przynosi tymczasem pierwszorzędne informacje o stosunkach polsko-litewskich i otoczeniu królewskim oraz uzupełnia wiadomości przekazane przez Jana Długosza i inne źródła dotyczące wojny na Wołyniu latem 1431 r. Przy dyplomie zachowało się również kilka pieczęci polskich gwarantów, co powiększa istniejącą wiedzę o sfragistyce polskich możnowładców. Ponadto wydawane tu źródło jest dość trudno dostępne: kiedy jeden z piszących te słowa zamówił je po raz pierwszy w Rosyjskim Archiwum Państwowym Akt Dawnych w 2007 r., otrzymał jedynie odpisy dziewiętnastowieczne, bez żadnych informacji o losie oryginału, jak gdyby go tam w ogóle nie było. Wszystkie te okoliczności uzasadniają potrzebę krytycznej edycji tego źródła.

Wypada jeszcze odnieść się krótko do problemów terminologicznych dotyczących rozejmów kończących wojnę na Wołyniu. Rozejm, który wszedł w życiu na mocy publikowanego tu dokumentu z 20 sierpnia, określamy umownie jako ,łucki” (od miejsca wystawienia dokumentu królewskiego), natomiast ten uzgodniony 26 sierpnia nazywamy „czartoryskim” (od miejsca wystawienia potwierdzającego go dokumentu wielkiego księcia Świdrygiełły) ${ }^{11}$. Taka właśnie terminologia odnosząca się do drugiego z rozejmów zakorzeniła się już bowiem w historiografii. Warto tu wszakże podkreślić, że dokument królewski w swoich obu datacjach (26 VIII i 2 IX) wymienia Łuck jako miejsce wystawienia ${ }^{12}$. Także współcześni rozejm ten określali jako rozejm zawarty ,pod Łuckiem”, odnosząc się właśnie do miejsca wystawienia dokumentu ${ }^{13}$.

Publikowany dokument rzuca światło na stosunki polsko-litewskie po śmierci wielkiego księcia Witolda. Zaostrzyły się one już pod koniec jego życia, gdy w 1429 r. przyjął propozycję króla rzymskiego Zygmunta Luksemburskiego, aby

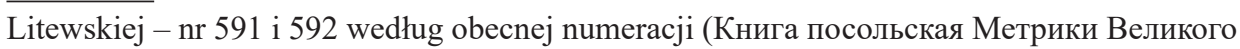
княжества Литовского, содержащая в себе дипломатические сношения Литвы в государствование короля Сигисмунда Августа с 1545 по 1572 год, ч. 1-2, изд. М. Оболенский, И. Данилович, М. Погодин, Д. Дубенский, Москва 1843). Być może związane z tym było tłumaczenie dokumentu na język rosyjski, uwierzytelnione przez M. Oboleńskiego. Jest ono prawie identyczne z przekładem z 1813 r., zawiera jedynie drobne poprawki nieznacznie modernizujące język (zob. niżej, w edycji).

${ }^{9}$ Index actorum saeculi XV ad res publicas Poloniae spectantium, wyd. A. Lewicki, Kraków 1888, nr 1698.

10 A. G ą s i o r o w s k i, Itinerarium króla Władysława Jagiełły 1386-1434, Warszawa 1972 , s. 91, w drugim wydaniu tej pracy $(2015$, s. 119) podana już została sygnatura archiwalna dokumentu wskazana przez S. Polechowa, niestety jednak niedokładnie - powinno być op. $\mathrm{nr} 3$, a nie nr 1, podczas gdy dokładną sygnaturę podano w niewłaściwym miejscu - na s. 118, pod 6-10 VI.

11 Б. Бу ч и н с ь к и й, Кілька причинків до часів вел. князя Свитригайла (1430-1433), Записки наукового товариства ім. Шевченка 76, 1907, s. 131-137.

12 Zob. przyp. 5.

13 Tak np. w nagłówku krzyżackiego odpisu dokumentu rozejmu czartoryskiego wystawionego przez stronę polską: „Copie des beyfredes, der gemacht ist czwuschen dem konige von Polan unde dem grosfurste, dor eyn ouch ist geczogen der homeyster unde seyn Orden mit eren helfern unde beylegern, der gemacht ist vor Lawczk in Rewsen etc., den brochte Segmund Rothe mit eyner credencie czu Marienburg" (GSPK, XX. HA, OF 14, s. 633). 
koronować się na króla Litwy, co zapoczątkowało okres tzw. burzy koronacyjnej ${ }^{14}$. Kiejstutowicz nie doczekał się jednak koronacji - zmarł 27 X 1430 r. Stolec wielkoksiążęcy, wbrew postanowieniom unii horodelskiej, zajął wówczas Bolesław Świdrygiełło Olgierdowicz - rodzony brat Władysława Jagiełły i długoletni rywal Witolda $^{15}$. Praktycznie od razu doszło do sporu o Podole Zachodnie, które Jagiełło przekazał Witoldowi w dożywocie w 1411 r. Mimo że Kiejstutowicz próbował tam umocnić swoje panowanie, po jego śmierci terytorium to od razu uznało władzę króla polskiego, choć Świdrygiełło przez pewien czas więził go na Litwie i dopiero podjęte w Polsce przygotowania do wojny zmusiły wielkiego księcia do uwolnienia więźnia $^{16}$. Jagiełło po powrocie do Polski zaczął utwierdzać swoją władzę na Podolu Zachodnim. Strona litewska nie zdołała już odzyskać tego terytorium ${ }^{17}$, ale też nie powiodły się próby zajęcia przez stronę polską Podola Wschodniego, pozostającego pod władzą wielkiego księcia ${ }^{18}$. Polacy i ich monarcha ośmieleni sukcesem postanowili jednak zająć sąsiadującą z Podolem ziemię łucką na Wołyniu, zwłaszcza że Świdrygiełło był zajęty negocjacjami w sprawie sojuszu wojskowego z Zygmuntem Luksemburskim, Zakonem Krzyżackim (z którym zawarł przymierze w Skirstymoniu 19 VI 1431 r. $^{19}$ ) i innymi sąsiadami. Wojna wybuchła pod koniec czerwca 1431 r.,

14 G. B ł a s z c z y k, Burza koronacyjna. Dramatyczny fragment stosunków polsko-litewskich w XV wieku, Poznań 1998; t e n ż e, Dzieje stosunków polsko-litewskich, t. II, cz. 1, Poznań 2007, s. 505-582; J. D ü c k e r, Sigismund und der Konflikt um die Königskrönung Witolds von Litauen (1429/30), w: Emperor Sigismund and the Orthodox World, Wien 2010, s. 17-25; R. P e tra u s k a s, Korona Witolda: niedoszła koronacja i jej późniejsza legenda historyczna, w: Tradycja - metody przekazywania i formy upamiętniania w państwie polsko-litewskim, XV - pierwsza połowa XIX wieku, Warszawa 2011, s. 13-23; J. N i k o d e m, Witold, wielki książę litewski (1354 lub 1355 - 27 października 1430 roku), Kraków 2013, s. 381-422; P. B a r, Der „Krönungssturm“: König Sigismund von Luxemburg, Grossfürst Witold von Litauen und das gescheiterte politische Bündnis, Roczniki Historyczne 83, 2017, s. 65-101. Tu i dalej wskazujemy ostatnie prace, w których znajduje się starsza literatura i źródła do omawianej problematyki.

15 J. Nik o de m, Wyniesienie Świdrygiełly na Wielkie Księstwo Litewskie, Białoruskie Zeszyty Historyczne 19, 2003, s. 5-31; G. B ła s z c zy k, Dzieje, t. II/1, s. 617-624; C. В. П ол ех о в, Наследники, s. 148-176; nic nowego nie wnosi K. O s iń s k i, Przejęcie stolca wielkoksiążęcego przez Świdrygiełłę. Próba rekonstrukcji wydarzeń do końca 1430 roku, Białoruskie Zeszyty Historyczne 43, 2015, s. 7-33, podobnie jak t e nż e, Rządy wielkoksiążęce Świdrygiełly w latach 1430-1432, tamże 45, 2016, s. 7-45.

16 O sytuacji na Zachodnim Podolu zob. J. K u r ty k a, Podole w średniowieczu i okresie nowożytnym. Obrotowe przedmurze na pograniczu cywilizacji, w: tegoż, Podole w czasach jagiellońskich, Kraków 2011, s. 125-130; В. М и х а й л о в с ь к и й, Еластична спільнота. Подільська шляхта в другій половині XIV - 70-х роках XVI століття. Київ, 2012, s. 97-116; t e n ż e, Podole po Grunwaldzie (1410-1430). Walka Witolda z Jagiełłą, w: Jogailos ir Vytauto laikai. Mokslinių straipsnių rinkinys, skirtas Žalgirio mūšio 600-osioms metinėms, Kaunas 2011, s. 117-125; С. В. П о ле х о в, Наследники, s. 176-183.

17 Codex epistolaris saeculi decimi quinti, t. II, wyd. A. Lewicki, Kraków 1891, nr 191; Joannis Dlugossii Annales seu Cronicae incliti Regni Poloniae (dalej cyt.: Długosz), lib. XI-XII, Varsaviae 2001, s. 14.

18 Informował o tym Świdrygiełło w listach do wysokich dostojników krzyżackich: GSPK, XX. HA, OBA, nr 5597, 5633.

19 Liv-, est- und kurländisches Urkundenbuch, Abt. I, t. VIII, nr 462; Die Staatsverträge, t. I, nr 171; odpisy nieuwzględnione przez wydawców: Kraków, Biblioteka Książąt Czartoryskich, 
gdy wojska polskie wkroczyły na terytorium Wielkiego Księstwa ${ }^{20}$. Mimo istniejącego przez cały ten czas napięcia w stosunkach polsko-litewskich wielki książę był nieprzygotowany do takiego rozwoju wydarzeń, nie okazał też talentów militarnych. W ziemi łuckiej Polacy nie mogli oprzeć się na miejscowej szlachcie, której postawa zdecydowała o zajęciu Podola Zachodniego. Próba ustanowienia lennego wobec Korony księstwa Fedora Lubartowicza z centrum we Włodzimierzu, gdzie panował on już 40 lat wcześniej, zakończyła się niepowodzeniem w związku z jego śmiercią, która nastąpiła zapewne na przełomie sierpnia i września $1431 \mathrm{r}$. Polacy wreszcie, chociaż udało im się odnieść zwycięstwo w bitwie pod Łuckiem i nawet wziąć do niewoli kilku dostojników litewskich, nie zdołali opanować zamku łuckiego, a jego oblężenie przeciągnęło się ${ }^{21}$. Negocjacje polsko-litewskie prowadzone od lipca też nie przynosiły długo rezultatów, ale zbliżająca się jesień z nieuniknionym pogorszeniem pogody skłaniała obie strony do dalszych rozmów.

Podstawowym źródłem pozwalającym zrekonstruować przebieg wojny łuckiej pozostają Roczniki Jana Długosza, których wiadomości badacze starają się uzupełnić w miarę możliwości informacjami czerpanymi z innych przekazów - współczesnej korespondencji, rachunków miejskich, dokumentów rozejmowych i przywilejów dla osób prywatnych. Już dawno zauważono, że wspomniany kronikarz w opisie wojny łuckiej musiał dysponować jakimś współczesnym dobrze poinformowanym źródłem - może był to dziennik biskupa chełmskiego Jana Biskupca (co prawda jego obecności na Wołyniu w otoczeniu Jagiełły w sierpniu i wrześniu 1431 r. nie potwierdzają żadne przekazy ${ }^{22}$. Należy jednak pokreślić, że porównanie informacji wziętych z publikowanego niniejszym dokumentu z narracją Długosza dowodzi znacznej wiarygodności tej ostatniej, a zarazem istotnie ją uzupełnia. Dokument królewski rysuje obraz stosunków polsko-litewskich na Wołyniu w końcowej fazie wojny. Według Długosza 18 VIII 1431 r. do obozu królewskiego przybyli posło-

rkps 233, s. 477-480, 629-631; zob. też J. N i k o d e m, Stosunki Świdrygiełly z Zakonem Krzyżackim w latach 1430-1432, Białoruskie Zeszyty Historyczne 14, 2000, s. 5-32.

${ }^{20}$ O wojnie łuckiej zob. ostatnio G. Błas zczyk, Dzieje, t. II/1, s. 638-650; C. В. П о л е х о в, Наследники, s. 193-210; D. W r ó b e 1, Przyczynek prozopograficzny do dziejów tzw. wyprawy łuckiej z 1431 r., Res Historica 41, 2016, s. 239-252 (w tych pracach źródła i pozostała literatura przedmiotu); najnowsze prace poświęcone specjalnie wojnie łuckiej oparte są niestety jedynie na źródłach drukowanych (przede wszystkim Długoszu) i literaturze, zob. T. S t o la r c z y k, Świdrygiełło przeciwko Jagielle - tzw. wojna łucka w 1431 r., Mars 10, 2001, s. 3-18; Э. Л. П о л я н с к а я, «Угнетённая войной и опустошённая огнём» или Свидригайло против Ягайло в борьбе за Волынскую землю в освещении Яна Длугоша и польской историографии, w: Colloquia Russica, ser. I, t. II: Principalities in Lands of Galicia and Volhynia in International Relations in $11^{\text {th }}-14^{\text {th }}$ c., Kraków 2012, s. $165-171$.

${ }_{21}$ Źródła mówią o zamku łuckim w liczbie pojedynczej, ale faktycznie składał on się z dwóch przyległych do siebie części, rozdzielonych fosą-zamku górnego i okolnego. Według Długosza lib. XI-XII, s. 30-31, ,zamek otoczono ze wszystkich stron”, a król stacjonował w pobliżu kościoła św. Krzyża, położonego bardziej na północ (zob. С. Т е р с ь к и й, Лучеськ X-XV ст., Львів 2006, s. 36-65, 77, 91).

22 A. L e w i c k i, Powstanie Świdrygiełły. Ustęp z dziejów unii Litwy z Koroną, Kraków 1892, s. 317, przyp. 26; Rozbiór krytyczny Annalium Poloniae Jana Długosza z lat 1385-1444, t. I, Wrocław 1961, s. XLII, 257-260. 
wie Świdrygiełły - kniaziowie Olelko (Aleksander Włodzimierzowicz), Wasyl (Semenowicz Drucki zwany Krasnym), wojewoda wileński Jerzy Giedygołd oraz pięciu innych Litwinów - by pertraktować w sprawie zawarcia pokoju. Mimo kilkudniowych rozmów wielkoksiążęcy negocjatorzy opuścili obóz królewski, nie osiągnąwszy porozumienia. Doprowadzono jednak do zawarcia siedmiodniowego rozejmu. Czas jego trwania precyzuje publikowany tu dokument. Miał on trwać od dnia jego wystawienia do najbliższej niedzieli (a die date presencium usque ad diem dominicum proximum), czyli od 20 do 26 sierpnia. Długosz różni się tylko określeniem długości trwania, mówi bowiem o zawieszeniu działań na osiem dni, choć nie wiadomo od kiedy ${ }^{23}$. Różnica pomiędzy informacją z dokumentu i Rocznikami wydaje się związana z tym, że dziejopis znając, być może, termin końcowy (26 sierpnia), nie znał daty wystawienia dokumentu rozejmu łuckiego i uznał, że zaczynał się on dzień po przybyciu negocjatorów litewskich (czyli 19 sierpnia). Zgodnie z dokumentem rozejmowym Jagiełły i panów polskich Świdrygiełło zobowiązał się przybyć 23 sierpnia osobiście wraz z doradcami do obozu królewskiego w celu przeprowadzenia dalszych negocjacji. Według polskiego kronikarza przybyli tylko ci ostatni - kniaziowie Jerzy Semenowicz Holszański, wspomniany już Wasyl Drucki i jeszcze pięciu panów litewskich - i to dopiero 24 sierpnia $^{24}$. Sam Świdrygiełło się natomiast nie pojawił, zapewne z powodu obaw przed uwięzieniem przez stronę polską, którym dał wyraz w liście do wielkiego mistrza z 11 IX $1431 \mathrm{r}^{25}$ Ta runda pertraktacji została uwieńczona 26 sierpnia uzgodnieniem ostatecznego rozejmu ${ }^{26}$. W dniu 31 sierpnia wojewoda poznański Sędziwój z Ostroroga i kasztelan sieradzki Wawrzyniec Zaremba z Kalinowej dostarczyli uzgodniony tekst Świdrygielle do Czartoryska $^{27}$, gdzie nazajutrz książę wystawił odpowiedni dokument, zachowany do dziś w oryginale (stąd w literaturze określenie tego rozejmu jako czartoryskiego $)^{28}$. Jak wynika z drugiej daty umieszczonej w dokumencie królewskim, procedura zawarcia rozejmu została zakończona 2 września $^{29}$. Zapewne w tym dniu dostarczono

23 Długosz, lib. XI-XII, s. 33.

24 Tamże, s. 36.

25 Pisał wtedy, że nie chce spotkać się z królem Polski: „,on sachen wegen, czum yrsten, das uns nicht geschege, alse [sic] unsern vorfaren seliges gedechtniss herczog Wytold unseren lyeben bruder etc." (GSPK, XX. HA, OF 14, s. 644); chodzi tu o uwięzienie Witolda przez Jagiełłę wbrew gwarancjom bezpieczeństwa w 1381 r., czyli przed 50 laty.

26 Zob. przyp. 5 i odpowiadający mu tekst.

27 O negocjacjach i polskich negocjatorach wspominał również sam Świdrygiełło w liście do wielkiego mistrza Pawła von Rusdorfa 4 IX 1431 r.: „Wir wellen euch czu wissen seyn, das der koning von Polan nu am freytage vor Egidii [31 VIII 1431] czu uns hot gesant den herren Ostrorog czur Pony [sic] unde den Zarambe czu Syradz herre unde seyne getrawen, mit den wir alzo geteydingt unde vorricht haben, das wir czwuschen uns frede bys czu synte Johannes tage des Tewfers unde von dem selben Johannis tage czukomende nest abir czu dem andirn synte Johannes [sic] tage dornoch czukomende ingenomen haben unde mit kreftunge unsirn unde eren eyngesegil vorschreben haben" (GSPK, XX. HA, OF 14, s. 632); zob. też list wielkiego księcia do wielkiego marszałka i wielkiego komtura z tego samego dnia, w którym informował o zawarciu rozejmu (GSPK, XX. HA, OBA, nr 5764).

28 Kraków, Biblioteka Książąt Czartoryskich, perg. 374, edycja: Б. Бучи н с ьк и й, Кілька причинків, s. 131-137.

${ }_{29}$ Zob. przyp. 5. 
dokument wielkoksiążęcy do obozu królewskiego, gdzie odbyło się opieczętowanie dokumentu polskiego, który następnie dostarczono Świdrygielle.

Analiza treści dokumentu rozejmu łuckiego pozwala stwierdzić, że Polacy zdołali narzucić stronie litewskiej swoje warunki. Zezwolono bowiem ludziom z obozu królewskiego na korzystanie z paszy dla koni i łowisk, podczas gdy oblężonym zabroniono wychodzenia z zamku po drewno, paszę i wodę, pomimo że także oni zostali objęci rozejmem. Umieszczenie tego warunku wynikało z faktu, że - jak wiemy - oblężeni opuszczali zamek podczas zawieszenia broni w celu uzupełniania zapasó ${ }^{30}$. Koresponduje to również dobrze $\mathrm{z}$ wiadomością Długosza; pisał on o trudnych warunkach życia w polskim obozie (braku paszy dla koni i szerzeniu się wśród nich zarazy), które zmusiły króla i jego otoczenie do przyspieszenia rozmów o zawieszeniu działań wojennych ${ }^{31}$. Ponadto rycerz Henryk von Maltitz w swoim liście pisanym z Malborka 23 IX 1431 r., w którym zrelacjonował dotychczasowy przebieg wojny margrabiom miśnieńskim Fryderykowi i Zygmuntowi, wspominał, że Świdrygiełło wziął do niewoli pod Łuckiem wielu Polaków podczas wypraw po żywność i furaż (,vuterunge”) ${ }^{32}$. Jednocześnie rycerze polscy, o czym także wspomina Długosz, nie tracili nadziei na pomyślny wynik oblężenia i nawet 1 września, już po wysłaniu uzgodnionego tekstu dokumentu rozejmowego stronie litewskiej, próbowali je rozstrzygnąć na swoją korzyść za pomocą specjalnie zbudowanej machiny oblężniczej (,,proku”) ${ }^{33}$.

Warto jeszcze dodać, że w dokumencie królewskim znalazło się żądanie, aby strona litewska doprowadziła do wystawienia analogicznego dokumentu, który byłby umocniony pieczęciami Świdrygiełły i wielkoksiążęcych poddanych. Nie wiemy jednak, czy został on w rzeczywistości wystawiony, gdyż szybko została podjęta kolejna faza rokowań i wypracowano zasady ostatecznego zawieszenia broni.

Publikowany dokument przynosi również ciekawe informacje o tym, w jaki sposób strona polska postrzegała kontrahentów litewskich. Oto bowiem Świdrygiełło został w nim określony kilkakrotnie „księciem”, co oznacza, że nie uznawano jego tytulatury wielkoksiążęcej. Podobnie postąpiono zresztą później w dokumencie rozejmu czartoryskiego ${ }^{34}$. Nie było to na pewno dziełem przypadku, ponieważ sam Świdrygiełło skarżył się posłom zakonnym w lutym 1432 r., po otrzymaniu glejtu na zjazd z królem, że ten tytułuje go w swoich pismach jedynie księciem, podczas gdy papież, król rzymski i inni władcy nazywają go wielkim księciem ${ }^{35}$.

30 Długosz, lib. XI-XII, s. 32.

31 Tamże, s. 34-35.

32 Codex epistolaris saeculi decimi quinti, t. III, Kraków 1894, dod. nr 8.

33 Długosz, lib. XI-XII, s. 36-38.

${ }^{34}$ GSPK, XX. HA, OF 14, s. 637-643.

35 Donosił o tym wielkiemu mistrzowi wójt z Bratianu 2 II 1432 r.: „Och, genediger her meister, so wisset, daz gar vorsinelich waz dem grosfursten, daz im der koning schreiff slecht herczog czu Littauwen etc. und nicht grosfurste, und sprach czu den Polen: der helige vather der bobest, der Romissche koning und alsust alle ander heren screiben uns grosfurste, ane alleyne unsir brudir konig czu Polen mit den seynen alzo daz wir dorynne irkennen, daz uns der koning und dy Polen eyn sulches nicht en gunnen" (GSPK, XX. HA, OBA, nr 5942); rzeczywiście, z wyjątkiem ugody trockiej z 7 XI 1430 r., zachowanej co prawda w odpisie (Codex epistolaris Vitoldi, nr 1461), Władysław Jagiełło tytułował Świdrygiełłę po prostu 
Jak widać, zawarcie 20 VIII 1431 r. rozejmu łuckiego wynikało z bieżących potrzeb, związanych z tymczasowym zawieszeniem negocjacji, które rozpoczęły się 18 sierpnia. Miał on dać stronom konfliktu czas na podjęcie i sfinalizowanie kolejnej rundy rozmów. Znalazły się w nim zatem postanowienia dotyczące najbliższego wobec miejsca rokowań teatru działań zbrojnych.

Generalne zasady zawieszenia broni w wojnie polsko-litewskiej zostały natomiast ujęte dopiero w wynegocjowanym w trakcie trwania rozejmu łuckiego rozejmie czartoryskim. Sprecyzowano w nim bardzo długi czas jego obowiązywania (do 24 VI 1433 r.). Strony zachowywały status quo sprzed wojny łuckiej: Podole Zachodnie pozostawało pod władzą Polski, Wschodnie zaś - Litwy, z tym że zamek w Bakocie miał zostać zniszczony. W czasie trwania rozejmu czartoryskiego miał się nadto odbyć 2 II 1432 r. zjazd władców Polski i Litwy oraz ich doradców w celu przeprowadzenia rokowań o trwały pokój. Mimo że rozejm obejmował również sojuszników Świdrygiełły, czyli Zakon Krzyżacki, Tatarów i Mołdawian, 28-29 VIII 1431 r. wojska zakonne na wcześniejsze usilne prośby Świdrygiełły, kierowane do wielkiego mistrza od początku wojny, uderzyły z Prus na północną część Polski ${ }^{36}$.

Poruszenia wymaga również kwestia dotycząca tego, kto odpowiadał za wygotowanie polskiego dokumentu rozejmu łuckiego, powstałego wszak w szczególnych okolicznościach - „w polu”. Bardzo ważne dane na ten temat znajdujemy w dziele Jana Długosza, który informując o opuszczeniu przez biskupa krakowskiego Zbigniewa Oleśnickiego oraz podkanclerzego Władysława Oporowskiego obozującego w Uściługu korpusu wojsk królewskich, wspomniał, że pieczęć Jagiełły, znajdująca się w pieczy podkanclerzego, została powierzona kustoszowi sandomierskiemu Mikołajowi Drzewickiemu herbu Ciołek ${ }^{37}$. Zatem to właśnie Drzewicki pod nieobecność kanclerza i podkanclerzego (o czym jeszcze niżej) był kierownikiem „,polowej” kancelarii królewskiej podczas wojny na Wołyniu ${ }^{38}$. Niewątpliwie to on zatem co

księciem, zarówno w korespondencji (GSPK, XX. HA, OF 14, s. 617, 627; Codex epistolaris saeculi decimi quinti, t. II, nr 191, 192, 194, t. III, dod. nr 6), jak i nadaniach za zasługi w tej wojnie (Zbiór dokumentów małopolskich, wyd. I. Sułkowska-Kuraś, S. Kuraś, cz. I-VIII, Wrocław 1962-1975 [dalej cyt.: ZDM], tu cz. VII, nr 2083; Materiały archiwalne wyjęte głównie z Metryki Litewskiej od 1348 do 1607 roku, wyd. A. Prochaska, Lwów, 1890, nr 75 = Matricularum Regni Poloniae codices saeculo XV conscripti, t. I, wyd. A. Mysłowski, W. Graniczny, Warszawa 1914, nr 7).

${ }_{36}$ M. B i s k u p, Najazd krzyżacki na Polskę i bitwa pod Dąbkami 1431 r., w: Studia historyczne. Stanisławowi Herbstowi na sześćdziesięciolecie urodzin w upominku uczniowie, koledzy, przyjaciele, Warszawa 1967, s. 15-28; t e n ż e, Wojny Polski z Zakonem Krzyżackim (1308-1521), Gdańsk 1993, s. 145-153; D. W r ó b e 1, Elity polityczne Królestwa Polskiego wobec problemu krzyżackiego w czasach Władysława Jagiełły, Lublin 2016, s. 460-467.

37 Długosz, lib. XI-XII, s. 26.

38 Mikołaj z tytułem sekretarza królewskiego wystąpił w formule relacyjnej większości Jagiełłowych dokumentów wystawionych w drodze pod Łuck, podczas działań zbrojnych i w trakcie powrotu z Wołynia (ZDM VII, nr 2081, 2082, 2084, 2085; J. K r z y ż a n i a k o w a, Kancelaria królewska Władysława Jagiełły. Studium z dziejów kultury politycznej w XV wieku, cz. 2, Poznań 1979, s. 125), tylko raz relatorem był kasztelan krakowski Mikołaj Białucha z Michałowa (ZDM VII, nr 2083), w związku z czym już dawniej przypuszczano, że Drzewicki był faktycznym kierownikiem kancelarii królewskiej podczas pobytu Władysława Jagiełły na Litwie w 1430 i wojny łuckiej w 1431 r. Zob. o nim I. S ułk ow s ka-Kura si owa, 
najmniej nadzorował sporządzenie interesującego nas dokumentu. Nie mamy jednak pewności, czy Drzewicki go osobiście ułożył lub spisał, wydaje się bowiem pewne, że pod Łuckiem towarzyszył mu niższy personel kancelaryjny. Problem ten może być rozwiązany tylko w drodze szczegółowej analizy rąk pisarzy dokumentów Władysława Jagiełły z tego okresu.

Warto także zastanowić się, w jaki sposób dokument Jagiełły z 20 VIII $1431 \mathrm{r}$. znalazł się w Moskwie. Wnioskując z praktyki znanej z okresu wojny z Zakonem Krzyżackim w latach 1409-1411, dokumenty rozejmowe pozostawały w rękach odbiorcy, czyli przeciwnej strony konfliktu, nawet po zawarciu kolejnego rozejmu lub pokoju ${ }^{39}$. To pozwala przypuszczać, że i nasz dokument pozostał w Wielkim Księstwie Litewskim zarówno po zawarciu rozejmu czartoryskiego, jak i po wyniesieniu na stolec wielkoksiążęcy Zygmunta Kiejstutowicza, który przejął archiwum Świdrygiełły i przekazał do Polski dokumenty dotyczące przymierza tego ostatniego z Krzyża$\mathrm{kami}^{40}$. Wprawdzie nie udało się dotąd odnaleźć żadnych wzmianek o dokumencie Jagiełły w źródłach informujących o archiwach Wielkiego Księstwa Litewskiego, jednak wydaje się, że pozostawał on tam najpewniej jeszcze na przełomie XV i XVI stulecia. Przekonuje o tym fakt, że najstarsza nota dorsalna została sporządzona w języku łacińskim, mieszanym pismem kursywnym z silnymi elementami pisma humanistycznego lub renesansowego, zapewne w ostatniej ćwierci XV lub początku XVI w. ${ }^{41}$ Nie potrafimy jednak wskazać jak dotąd innych dokumentów, których noty dorsalne byłyby sporządzone podobnym typem pisma, co dałoby podstawy do wnioskowania o konkretnym miejscu przechowywania. Natomiast pierwsza wzmianka o dokumencie Jagiełły w archiwalnej dokumentacji moskiewskiej znajduje się dopiero w inwentarzu archiwum prikazu poselskiego z 1673 r., w dziale „gramot polskich" ${ }^{\text {" } 2}$. Wiadomo, że wówczas poprzedni inwentarz, sporządzony w $1627 \mathrm{r}^{43} \mathrm{i}$ obejmujący całość archiwum, został uzupełniony przede wszystkim o nowe dokumenty z lat 1634-1673, natomiast dane o najdawniejszych dokumentach zostały przejęte z owego starszego spisu ${ }^{44}$. Każe to przypuszczać, że dokument Jagiełły dostał się do Moskwy

Dokumenty królewskie i ich funkcje w państwie polskim za Andegawenów i pierwszych Jagiellonów 1370-1444, Warszawa 1977, s. 208-209; J. K r z y ż a n i a k o w a, Kancelaria, cz. 2, s. 123-126; L. P o n i e w o z i k, Prałaci i kanonicy sandomierscy w okresie średniowiecza, Toruń 2004, s. 255-258; P. D e m b i ń s k i, Poznańska kapituła katedralna schyłku wieków średnich. Studium prozopograficzne 1428-1500, Poznań 2012, s. 534-536.

${ }^{39}$ A. S zwe da, Uwagi o dokumentach rozejmowych i pokojowych z okresu wojny 1409-1411, Zapiski Historyczne 75, 2010, z. 2, s. 68-74.

${ }^{40}$ Taki warunek przewidywał już akt unii grodzieńskiej z 15 X 1432 r. (Akta unii Polski z Litwą 1385-1791, wyd. S. Kutrzeba, W. Semkowicz, Kraków 1932, nr 55).

${ }_{41}$ Tak scharakteryzowała pismo dr Rūta Čapaitė z Wilna, której serdecznie dziękujemy.

42 Опись архива Посольского приказа 1673 года, подг. В. И. Гальцов, ред. С. О. Шмидт, ч. I, Москва 1990, s. 217, 227.

43 Опись архива Посольского приказа 1626 года, подг. В. И. Гальцов, ред. С. О. Шмидт, ч. I, Москва 1977; choć w tytule edycji występuje rok 1626, to rozkaz o sporządzeniu inwentarza pochodzi z 25 XII, a prace nad nim zostały podjęte dopiero w następnym roku (tamże, s. 7-8, 23-24; В. А. Ку ч к и н, Договорные грамоты московских князей XIV века. Внешнеполитические договоры, Москва 2003, s. 119, przyp. 3).

${ }^{44}$ Опись архива 1673, ч. I, s. 8. Nabytki z lat 1627-1632 obejmuje inwentarz sporządzony w 1. 1632-1634 (tamże, s. 5); wzmianki o naszym dokumencie brakuje też w inwentarzu 
w połowie XVII w., kiedy tuż przed szwedzkim potopem wojska rosyjskie opanowały znaczną część Wielkiego Księstwa Litewskiego i zajęły Wilno, w sierpniu 1655 r. $\mathrm{W}$ inwentarzu opis naszego dokument jest poprzedzony bezpośrednio przez inny regest: „Привилей польского Владислава короля, писан в Литву всяких чинов людем о хрещении, на паргамине, латинским письмом" ${ }^{\prime 4}$. Chodzi tu może o przywilej Władysława Jagiełły dla litewskich bojarów katolików z 20 II 1387 r., obecnie znany jedynie z odpisu w Metryce Litewskiej ${ }^{46}$. Tego dokumentu również nie ujęto, mimo jego pierwszorzędnej wagi, we wcześniejszych inwentarzach archiwum poselskiego prikazu. Wydaje się, że oba dokumenty znajdowały się w tej samej części archiwum Wielkiego Księstwa Litewskiego i zostały z niego zabrane w jednym czasie. O ile jednak żadne późniejsze, już osiemnasto- i dziewiętnastowieczne, rosyjskie inwentarze archiwalne nie wspominają o przywileju Jagiełły „o chrzcie”, o tyle dokument rozejmowy z $1431 \mathrm{r}$. występuje w inwentarzach wspomnianego archiwum, które w latach dwudziestych XVIII stulecia zostało przekształcone w Moskiewskie Archiwum Kolegium Spraw Zagranicznych (Московский архив Коллегии иностранных дел - МАКИД) ${ }^{47}$. Dopiero w 1766 r. słynny uczony, Niemiec w służbie rosyjskiej, Gerhard Friedrich Müller (1705-1783) podjął się systematyzacji tego archiwum i zwrócił uwagę na dokument z $1431 \mathrm{r}$., gdyż od daty jego wystawienia miał zaczynać się $\mathrm{w}$ jego koncepcji archiwalny dział mieszczący traktaty zawarte pomiędzy Rosją a Polską ${ }^{48}$. Pracę tę kontynuowali z powodzeniem w drugiej połowie XVIII i na początku XIX w. współpracownicy G. F. Müllera: Nikołaj Bantysz-Kamienski (1737-1814) i Aleksiej Malinowski (1762-1840). Pierwszy z nich zestawił wiele dotąd wykorzystywanych inwentarzy, w tym dokumentów o stosunkach Rosji z Polską ${ }^{49}$. W 1832 r., wraz z przekształceniem Kolegium w Ministerstwo, archiwum otrzymało nazwę Moskiewskiego Głównego Archiwum Ministerstwa Spraw Zagranicznych (Московский главный архив Министерства иностранных дел - МГАМИД), pod którą istniało do 1918 r. Po przekształceniach porewolucyjnych materiały archiwum w 1931 weszły w skład Państwowego Archiwum Epoki Feudalno-Pańszczyźnianej (Государственный архив феодально-крепостнической эпохи - ГАФКЭ), które w 1941 zmieniło nazwę na Centralne Archiwum Państwowe Akt Dawnych ZSRR, w 1992 r. zaś zostało przemianowane na Rosyjskie

archiwum carskiego z połowy XVI w. oraz w opisie archiwum prikazu poselskiego z 1614 r. (Описи царского архива XVI века и архива Посольского приказа 1614 года, ред. С. О. Шмидт, Москва 1960; Государственный архив России XVI столетия: Опыт реконструкции, подг. А. А. Зимин, ред. Л. В. Черепнин, вып. 1-3, Москва 1978).

45 Опись архива 1673, ч. I, s. 227.

46 Lietuvos metrika. Knyga Nr. 25. Užrašymų knyga 25, wyd. D. Antanavičius, A. Baliulis, Vilnius 1997, nr 1, s. 35-37; według J. J a kubows ki e g o, Archiwum państwowe W. X. Litewskiego i jego losy, Archeion 9, 1931, s. 8, 16, przywilej ten jeszcze w XVIII w. znajdować się miał w archiwum Radziwiłłów; sprawa ta zasługuje na specjalne zbadanie.

${ }_{47}$ Г. А. Д ре м и н а, Из истории Центрального государственного архива древних актов СССР, Москва 1959, s. 24-28.

48 Tamże, s. 48-49; С. Р. Д о л го в а, Г. Ф. Миллер и Московский архив Коллегии иностранных дел 1766-1783 гг., Исторический архив 2006, nr 1.

49 Obecnie stanowią w RGADA fond nr 79 „Stosunki Rosji z Polską”, opis 3 tego zespołu obejmujący dokumenty oryginalne ma na okładce datę: 1801. 
Archiwum Państwowe Akt Dawnych (Российский государственный архив древних актов - РГАДА $)^{50}$.

Publikowany tu dokument rozejmu łuckiego z 20 VIII 1431 r. stanowi ważne źródło dla poszerzenia wiedzy o otoczeniu króla Władysława Jagiełły podczas oblężenia Łucka i uczestnikach wyprawy na Wołyń. Problematyką tą jak dotąd zajął się najpełniej Grzegorz Błaszczyk, podając wykaz kilkudziesięciu uczestników wojny łuckiej, oparty na liście gwarantów rozejmu czartoryskiego i relacji Długosza ${ }^{51}$. Do kwestii tej nawiązał również Dariusz Wróbel, który w swoim opracowaniu na podstawie niewykorzystanego dotąd w pełni materiału źródłowego dokonał identyfikacji 45 Małopolan, którzy 3 VII 1431 r., tuż przed wyruszeniem na Wołyń, wystawili w Bystrzycy (zapewne miejscu koncentracji pospolitego ruszenia małopolskiego) listy wypowiednie do Świdrygiełły ${ }^{52}$. Uwzględniając publikowany w niniejszym artykule akt rozejmu łuckiego, podjąć można podsumowanie tej sprawy. Dokument z 20 VIII 1431 r. informuje nas o 17 gwarantach, którzy zobowiązali się przywiesić doń swoje pieczęcie. Na pierwszym miejscu wśród nich został umieszczony książę mazowiecki z linii płockiej Siemowit V, syn ukochanej siostry króla Władysławy Jagiełły i jego ulubiony siostrzeniec ${ }^{53}$. Za nim wciągnięto wysokich urzędników koronnych: kasztelana krakowskiego Mikołaja Białuchę z Michałowa, wojewodę poznańskiego Sędziwoja z Ostroroga, wojewodę kaliskiego Andrzeja z Danaborza, wojewodę sieradzkiego Marcina z Kalinowej, wojewodę łęczyckiego Ścibora z Borysławic, wojewodę inowrocławskiego Jaranda z Brudzewa (Grabia), wojewodę brzeskiego Jana z Lichenia, kasztelana poznańskiego Marcina ze Sławska, kasztelana gnieźnieńskiego Piotra z Bnina, kasztelana kaliskiego Piotra z Żernik, kasztelana sieradzkiego Wawrzyńca Zarembę z Kalinowej, kasztelana łęczyckiego Wojciecha Malskiego, kasztelana wojnickiego Dobiesława z Oleśnicy, kasztelana sądeckiego Krystyna z Koziegłów, kasztelana brzeskiego Krystyna ze Smólska, kasztelana dobrzyńskiego Jana Kretkowskiego i marszałka Królestwa Jana Głowacza z Oleśnicy ${ }^{54}$. Analiza zachowanych przy rozejmie łuckim pieczęci ${ }^{55}$ ujawniła jednak gwaranta,

50 Центральный государственный архив древних актов СССР. Путеводитель в 4 томах, т. I, Москва 1991, s. 24-25.

${ }^{51}$ G. B $ł$ a s z c z y k, Dzieje, t. II/1, s. 641-642.

52 D. W r ó b e 1, Przyczynek, s. 239-252; źródło to, jednak tylko ze streszczeń, znał także G. Błaszczyk, Dzieje, t. II/1, s. 639, w związku z czym nie potrafił go w pełni wyzyskać, a miejsce wystawienia zidentyfikował nietrafnie jako „Biskupice Ruskie koło Włodzimierza Wołyńskiego".

53 Stosunek pokrewieństwa łączący króla i księcia został zresztą w pełni oddany w źródle, w którym Siemowit został określony jako nepos noster carissimus.

54 Dane prozopograficzne dotyczące wszystkich z wymienionych zostały podane wraz $\mathrm{z}$ odwołaniami do literatury przedmiotu w przypisach rzeczowych do edycji.

55 Warto dodać, że obecna liczba zachowanych pieczęci (10 i jeden pasek pergaminowy $\mathrm{z}$ resztkami wosku) jest bardzo zbliżona do tej poświadczonej w odpisach i inwentarzach archiwalnych z początku XIX w., chociaż niewykluczone są niewielkie straty, oto bowiem w inwentarzu z $1801 \mathrm{r}$. (obecnie opis 3 fondu 79) pierwotna liczba 10 została wykreślona i poprawiona na 11, przy czym dodano, że 4 pieczęcie są uszkodzone, natomiast inwentarz z 1813 r. informuje o 10 pieczęciach (Отдел рукописей Российской государственной библиотеки, ф. 68 [Генеральный штаб], ед. хр. 301: Реестр договорам и грамотам европейских и азиатских дворов [1431-1724], л. 1), w odpisie zaś i tłumaczeniu z 1813 r. 
który nie został wymieniony w tekście, ale przywiesił jednak swoją pieczęć. Osoby tej nie można jednak zidentyfikować ze względu na słabo czytelną legendę pieczęci ${ }^{56}$. Źródłem komplementarnym w sprawie rekonstrukcji królewskiego otoczenia podczas wojny łuckiej jest wykorzystany najpełniej przez G. Błaszczyka ${ }^{57}$ akt rozejmu czartoryskiego z 2 IX 1431 r. Przekaz ten nie zachował się jednak, w przeciwieństwie do rozejmu łuckiego, w oryginale, ale wyłącznie w niemieckim thumaczeniu w krzyżackich księgach kancelaryjnych ${ }^{58}$. Obok wymienionego wyżej Siemowita V oraz urzędników ziemskich, którzy byli gwarantami rozejmu łuckiego (z wyjątkiem Krystyna ze Smólska oraz Jana Kretkowskiego), wymieniono tu także książąt płockich Kazimierza i Władysława (braci Siemowita V i siostrzeńców Jagiełły) ${ }^{59}$, kasztelana wiślickiego Floriana z Korytnicy ${ }^{60}$, kasztelana bieckiego Domarata z Kobylan ${ }^{61}$,

znajdujemy informację o 11 pieczęciach (РГАДА, ф. 79, оп. 3, ед. хр. 1, л. 3v, 7v). Widać, że dziewiętnastowieczni archiwiści mieli problem $\mathrm{z}$ ustaleniem jednoznacznych kryteriów stopnia zachowania pieczęci.

56 Zob. edycja; wiadomo, że nosił imię Jan, a pisał się „,de win[?]ols[...]” i posługiwał się herbem Odrowąż. Już podczas koncentracji armii królewskiej, 28 VI 1431 r. w obozie pod Zamchem towarzyszył Jagielle sędzia sandomierski Jan ze Sprowy herbu Odrowąż - zob. o nim Urzędnicy małopolscy XII-XV wieku. Spisy, Wrocław 1990 (dalej cyt.: UM), s. 211, 301-302, 362; Uzupełnienia do spisów urzędników małopolskich XII-XVIII wieku, w: Burgrabiowie zamku krakowskiego XIII-XV wieku. Spisy, opr. W. Bukowski, Kórnik 1999, s. 94, 101; B. C zw oj d rak, Zofia Holszańska. Studium o dworze i roli królowej w późnośredniowiecznej Polsce, Warszawa 2012, s. 146-147, 218. Widać go również przy królu podczas drogi powrotnej spod Łucka (Żukowice 14 IX, Lublin 17 IX, Bystrzyca 21 IX, ponownie Żukowice 24 IX) - zob. Нацыянальны гістарычны архіў Беларусі, ф. 1795, воп. 2, адз. 3ax. 1a (księga ziemska lubelska z lat trzydziestych XV w. - dalej cyt.: KzlMińsk), k. 3-4; Inscriptiones clenodiales ex libris iudicialibus palatinatus Cracoviensis, wyd. B. Ulanowski, Starodawne prawa polskiego pomniki, t. VII, cz. 3, Kraków 1885, s. 605; ZDM VII, nr 2081, 2085. Jest zatem raczej pewne, że brał udział w wojnie na Wołyniu, jednak bardzo wątpliwe, aby sędzia ziemski nie posiadał przy sobie własnego typariusza i posłużył się tłokiem pożyczonym od współrodowca. W otoczeniu Jagiełły podczas powrotnej drogi z wyprawy źródła potwierdzają także innego przedstawiciela rodu Odrowążów, kasztelana lubelskiego Jana ze Szczekocin (Żukowice 14 IX, Lublin 17 IX, Bystrzyca 21 IX - KzlMińsk, k. 3; ZDM VII, nr 2085). Brak jednak pewności, czy wracał on spod Łucka, w tym czasie był bowiem starostą dobrzyńskim i mógł udać się do króla z wieściami o najeździe krzyżackim, który nastąpił 29 VIII, jakkolwiek zupełny brak oporu podczas tego najazdu mógłby wskazywać, że Jana nie było w Dobrzyniu (zob. Urzędnicy kujawscy i dobrzyńscy XII-XV wieku. Spisy, Kórnik 2014 [dalej cyt.: UKD], s. 296, 312; M. B i s k u p, Wojny, s. 148). W jego przypadku także należy wątpić, aby tak wysoki urzędnik ziemski nie zabrał ze sobą własnej pieczęci.

57 G. B ła s z c z y k, Dzieje, t. II/1, s. 641-642; zob. też D. W ró be 1, Elity, s. 465, przyp. 350; S. S z y b k ow s k i, Jagiełło, Witold, Zofia Holszańska i polityka dynastyczna, Średniowiecze Polskie i Powszechne 8 (12), 2016, s. 312, przyp. 26.

58 Zob. przyp. 5.

59 O Kazimierzu II (zm. 1442) i Władysławie (zm. 1455) zob. K. J a s iń s k i, Rodowód Piastów mazowieckich, Poznań-Wrocław 1998 (recte: 2009), s. 125-130, 133-136.

${ }_{60}$ Florian z Korytnicy herbu Jelita był podczaszym sandomierskim 1400-1408, kasztelanem wiślickim 1410-1436 (UM, s. 188, 250, 339; Urzędnicy podolscy XIV-XVIII wieku. Spisy, Kórnik 1998, s. 116-117, 212; Urzędnicy województwa ruskiego XIV-XVIII wieku (ziemie halicka, lwowska, przemyska, sanocka). Spisy, Wrocław 1987, s. 149, 350).

${ }_{61}$ Domarat z Kobylan herbu Grzymała był kasztelanem bieckim 1410-1433, kasztelanem wojnickim 1433-1435, kasztelanem lubelskim 1435-1438, marszałkiem nadwornym 1428-1430 
kasztelana małogoskiego Pawła Złodzieja z Biskupic ${ }^{62}$, kasztelana kruszwickiego Mikołaja z Warzymowa ${ }^{63}$, kasztelana połanieckiego Stanisława Gamrata z Klimontowa ${ }^{64}$, kasztelana międzyrzeckiego Wincentego Świdwę z Szamotu1 ${ }^{65}$, kasztelana żarnowskiego Przybysława Dzika z Kadłuba ${ }^{66}$, podkomorzego krakowskiego Piotra Szafrańca (III) ${ }^{67}$, podkomorzego poznańskiego Piotra Korzboka z Trzebawia ${ }^{68}$, podkomorzego sandomierskiego Andrzeja Ciołka z Żelechowa ${ }^{69}$, podkomorzego kaliskiego Dobrogosta Świdwę z Szamotuł ${ }^{70}$, podkomorzego sieradzkiego Tomasza Szeligę z Janowic ${ }^{71}$ i podkomorzego łęczyckiego Stanisława Bielawskiego z Dobrzelina ${ }^{72}$.

(Urzędnicy centralni i nadworni Polski XIV-XVIII wieku. Spisy, Kórnik 1992, s. 83, 174; UM, s. 36-37, 141, 257, 291, 339).

${ }^{62}$ Paweł Złodziej z Biskupic herbu Niesobia był kasztelanem małogojskim 1426-1438, kasztelanem zawichojskim 1440-1445 (S. S z c z u r, Paweł zw. Złodziej, w: PSB XXV, s. 372373; UM, s. 79, 152, 261, 280, 375).

${ }_{63}$ Mikołaj z Warzymowa herbu Pomian był kasztelanem kowalskim 1418-1430, kasztelanem kruszwickim 1431-1435 (z tytułem tym po raz pierwszy wystąpił jako gwarant rozejmu czartoryskiego), kasztelanem brzeskim 1435-1454 (J. B i e n i a k, Mikołaj z Warzymowa, w: PSB XXI, s. 145-146; UKD, s. 182, 211, 219, 244; S. S z y b k o w s k i, Kujawska szlachta urzędnicza w późnym średniowieczu (1370-1501), Gdańsk 2006, s. 650).

64 Stanisław Gamrat z Klimontowa herbu Sulima był kasztelanem połanieckim 1413-1434 (UM, s. 160, 304, 330; Uzupełnienia, s. 89, 102).

${ }^{65}$ Wincenty Świdwa z Szamotuł herbu Nałęcz był kasztelanem międzyrzeckim 1423-1444 (T. J u r e k, Szamotulski Wincenty Świdwa, w: PSB XLVI, s. 587-588, 1999).

${ }_{66}$ Przybysław Dzik z Kadłuba herbu Doliwa był kasztelanem żarnowskim 1431-1436 (UM, s. 264, 299, 337; J. W r o n i s z e w s k i, „Nobiles Sandomirienses”. Rody Dębnów, Janinów, Grzymałów, Doliwów i Powałów, Kraków 2013, s. 151-153, 155, 157).

${ }^{67}$ Piotr (III) Szafraniec z Łuczyc, Pieskowej Skały herbu Starykoń, syn wojewody krakowskiego Piotra Szafrańca (II), był podkomorzym krakowskim 1431-1441 i krajczym nadwornym 1426 (J. S p e r k a, Szafraniec Piotr, w: PSB XLVI, s. 458-461).

68 Piotr Korzbok z Trzebawia herbu własnego był podkomorzym poznańskim 1426-1438 (A. G ą s i o r o w s k i, Korzbok Piotr, w: PSB XIV, s. 159; Urzędnicy wielkopolscy XII-XV wieku. Spisy, Wrocław 1985 [dalej cyt.: UW], s. 147-148, 151, 200).

69 Andrzej Ciołek z Żelechowa herbu Ciołek, brat podkanclerzego Królestwa i biskupa poznańskiego Stanisława Ciołka, był podkomorzym sandomierskim 1422-1436, starostą generalnym Wielkopolski 1434-1436 (UM, s. 842, 217, 302, 326; UW, s. 173, 203).

70 Dobrogost Świdwa z Szamotuł herbu Nałęcz, brat Wincentego, był podkomorzym kaliskim 1423-1436, kasztelanem poznańskim 1436-1450, starostą generalnym Wielkopolski 1430-1432, „opiekadlnikiem” wielkopolskim 1434-1438 (T. J u r e k, Szamotulski Dobrogost Świdwa, w: PSB XLVI, s. 565-569).

71 Tomasz Szeliga z Janowic, Wrześni, wbrew dotychczasowym ustaleniom posługiwał się herbem Poraj (Róża), a nie Szeliga (o czym świadczy jego pieczęć przywieszona pod dokumentem traktatu brzeskiego: Deutschordens-Zentralarchiv Wien, Urkunden, nr 3359); był podkomorzym sieradzkim 1423-1438 (Urzędnicy łęczyccy, sieradzcy i wieluńscy XIII-XV wieku. Spisy, Wrocław 1985 [dalej cyt.: UŁS], s. 116, 169; A. S z y m c z a k o w a, Szlachta sieradzka w XV wieku. „Magnifici et generosi”, Łódź 1998, s. 23, 92, 209, 223, 252, 272, 464).

72 Stanisław Bielawski z Dobrzelina herbu Doliwa był podkomorzym łęczyckim 14311450 (UŁS, s. 61, 77, 163; T. N o w a k, Własność ziemska w ziemi łęczyckiej w czasach Władysława Jagiełły, Łódź 2003, s. 345-346, 387). Wszystkich wymienionych wyżej polskich gwarantów rozejmu czartoryskiego jako uczestników działań na Wołyniu wylicza również G. B ła s z c z y k, Dzieje, t. II/1, s. 641-642, nie dokonuje jednak ich szczegółowej charakterystyki prozopograficznej, poprzestając na stwierdzeniu, że „większość z nich to postaci dobrze znane ze stosunków polsko-litewskich" (tamże, s. 642). 
Obecność części spośród gwarantów omówionych wyżej rozejmów w obozie pod Łuckiem dokumentuje również przywilej Jagiełły wystawiony tamże 17 VIII $1431 \mathrm{r}$. dla Jana Hryćki Kierdejowicza. W testacji umieszczono tam bowiem wspomnianych wyżej kasztelana krakowskiego, wojewodów poznańskiego, kaliskiego, sieradzkiego, łęczyckiego, brzeskiego i inowrocławskiego. Ci sami dostojnicy wraz z wymienionymi już wcześniej kasztelanami poznańskim, sieradzkim i łęczyckim, a także kasztelanem bydgoskim Wincentym Kiełbasą z Tymieńca byli również świadkami Jagiełłowego przywileju dla starosty samborskiego Piotra Odrowąża ze Sprowy (Zagórza) wystawionego 8 września $\mathrm{w}$ obozie pod Włodzimierzem, podczas drogi powrotnej spod Łucka $^{73}$. Wszystkich ich należy uznać za uczestników wojny.

Wydaje się, że podobny do wykorzystanych wyżej dokumentów królewskich walor poznawczy mają zapiski z ksiąg sądowych lubelskich dokumentujące posiedzenia sądów ziemskich w obecności króla (Lublin - 17 września, Żukowice - 14 i 24 września) oraz lista świadków dokumentu Jagiełły wystawionego w Bystrzycy (21 września) $)^{74}$. Zostały w nich wspomniane osoby wymienione już wyżej, a więc powracające z królem spod Łucka (wojewoda kaliski Andrzej z Danaborza i kasztelan bydgoski Mikołaj Kiełbasa). Źródła te dokumentują obecność przy monarsze również innych urzędników, którzy najpewniej brali udział w wyprawie: sędziego sandomierskiego Jana ze Sprowy ${ }^{75}$, marszałka nadwornego Jakuba Przekory z Morawian oraz kasztelana zawichojskiego Warsza z Ostrowa ${ }^{76}$. Poświadczają także

${ }^{73}$ ZDM VII, nr 2082, 2083. Mikołaj Kiełbasa z Tymieńca i Markowa herbu Nałęcz był kasztelanem bydgoskim 1426-1444 (UKD, s. 194, 244; S. S z y b k o w s k i, Kujawska szlachta, s. 623-624).

${ }^{74}$ KzlMińsk, k. 3-4; Inscriptiones clenodiales, s. 605; ZDM VII, nr 2085.

75 W przypadku sędziego Jana podnosiliśmy już wyżej, że najpewniej brał on udział w wojnie łuckiej, ponieważ towarzyszył królowi już podczas marszu na Wołyń (ZDM VII, nr 2081).

76 Jakub Przekora z Morawian herbu Doliwa był marszałkiem nadwornym 1431, kasztelanem czechowskim 1434-1452 i ochmistrzem królowej Zofii 1445-1449 (F. K i r y k, Przekora Jakub, w: PSB XXVIII, s. 719-720; B. C z w oj d r a k, Zofia Holszańska, s. 133-134, 219). Warsz z Ostrowa syn kasztelana krakowskiego Krystyna, był kasztelanem zawichojskim 1431-1438, kasztelanem lubelskim 1439-1443, „opiekadlnikiem” ziemi lubelskiej 1434-1438 (KzlMińsk, k. 146; UM, s. 141, 261, 299-300, 352; J. W r o n i s z e w s k i, Ród Rawiczów. Warszowice i Grotowice, Torun 1992, s. 20, 32-39, 154, 175). W tych samych źródłach wymienieni są także nieposiadający urzędów uczestnicy wojny: Spytek z Tarnowa starosta ruski 1422-1425, wojewoda sandomierski 1433-1434 (UM, s. 227, 368; Urzędnicy województwa ruskiego, s. 149, 398; W. D w o r z a c z e k, Leliwici Tarnowscy. Z dziejów możnowładztwa małopolskiego wiek XIV-XV, Warszawa 1971; Spytek jako członek rady wojennej prowadzącej działania na Wołyniu w zastępstwie króla (z anachronicznym tytułem wojewody sandomierskiego) został wymieniony także przez Długosza, zob. przypis następny), Jan Farurej z Garbowa herbu Sulima, brat Zawiszy Czarnego (Jan towarzyszył Jagielle zarówno podczas powrotu spod Łucka, jak i w marszu na Wołyń, w obozie pod Zamchem 28 VI 1431 r.: ZDM VII, nr 2081; był stolnikiem krakowskim 1434-1453, starostą spiskim 1428 - UM, s. 119, 331; B. M o ż e j k o, S. S z y b k o w s k i, B. Ś 1 i w iń s k i, Zawisza Czarny z Garbowa herbu Sulima, Gdańsk 2003, s. 40-41). Dodać jeszcze wypada, że niewątpliwie podczas kampanii wołyńskiej lub powrotu z niej doszło do podania w wątpliwość szlachectwa Jana Hinczy z Rogowa przez Wielkopolanina Andrzeja Nielataja z Wiśniewa, co stało się przedmiotem posiedzenia sądu królewskiego w Żukowicach 14 IX 1431 r. (KzlMińsk, k. 4; Inscriptiones clenodiales, nr 1613); Andrzej Nielataj był potem podstolim poznańskim (UW, s. 151, 202), 
obecność w otoczeniu Jagiełły byłego starosty ruskiego (lwowskiego) Spytka z Tarnowa (Jarosławia), którego uczestnictwo w wołyńskiej kampanii zaświadcza Długosz ${ }^{77}$.

Potrafimy zatem wykazać obecność przy królu pod Łuckiem 34 urzędników ziemskich oraz nadwornych. Oznacza to więcej niż podwojenie listy Długoszowej ${ }^{78}$.

Listy gwarantów obu rozejmów różnią się nieco od podobnych list, które umieszczano w poddawanych dotąd analizie dokumentach rozejmów polsko-krzyżackich z czasów Władysława Jagiełły. W ustalonym przez Antoniego Gąsiorowskiego standardzie traktatów ${ }^{79}$ mieści się uwzględnienie wśród gwarantów rozejmów łuckiego i czartoryskiego książąt mazowieckich i wysokich urzędników ziemskich, jednakże $\mathrm{z}$ jednym zastrzeżeniem. Brak tam bowiem zupełnie biskupów, którzy pojawiali się $\mathrm{z}$ reguły $\mathrm{w}$ innych polskich traktatach. Dotyczyło to nawet dokumentu pierwszego rozejmu z lat „wielkiej wojny” z Krzyżakami, zawartego 9 XII 1410 r. (jego gwarantem był, jakkolwiek jako jedyny duchowny, biskup płocki Jakub z Kurdwanowa). Jedynym dokumentem rozejmowym pozbawionym gwarantów duchownych był

a Jan Hincza podskarbim Królestwa i kasztelanem sieradzkim (B. C z w o j d r a k, Rogowscy herbu Działosza, podskarbiowie królewscy. Studium z dziejów możnowładztwa w drugiej połowie XIV i w XV wieku, Katowice 2002, s. 57-98). Za zasługi (ratione servitiorum) położone niewątpliwie właśnie podczas wojny łuckiej otrzymał od króla 19 IX 1431 r. zapis 50 grzywien na wsi Raków Sieradzanin Przecław Pomian z Woli Rozdziałowej (obecnie Rożdżały), później długoletni wicewojewoda w Sieradzu (1439-1452), klient wojewody sieradzkiego Jaranda z Brudzewa, jednego z gwarantów rozejmów łuckiego i czartoryskiego (ZDM VII, nr 2084; A. S z y m c z a k o w a, „Nobiles Siradienses”. Rody Porajów, Pomianów, Gryfów, Kopaczów i Pobogów, Warszawa 2011, s. 277, 278, 281, 282, 323). Za uczestników wyprawy wypada również, jak sugerowała już W. Z a w i t k o w s k a, W służbie pierwszych Jagiellonów. Życie i działalność kanclerza Jana Taszki Koniecpolskiego, Kraków 2005, s. 132-133, ze znacznym prawdopodobieństwem uznać Jana Taszkę i Przedbora z Koniecpola, niesprawujących jeszcze wówczas urzędów synów zmarłego wojewody sieradzkiego Jakuba, którzy świadkowali przy królu w Bystrzycy 21 IX 1431 r. (ZDM VII, nr 2085). Zgodnie z ustaleniami G. Błaszczyka, Dzieje, t. II/1, s. 642, w wyprawie uczestniczył także Jan Siennicki, za co w 1433 r. został przez króla nagrodzony.

77 Długosz, lib. XI-XII, s. 37.

78 Tamże, s. 28, 30, 33, 34, 36, 37. Relacja dziejopisa, wykorzystana już przez G. B ł a s z c z y k a, Dzieje, t. II/1, s. 642, podaje osoby z listy gwarantów obu rozejmów (Siemowit V i Kazimierz I, Dobiesław z Oleśnicy, Krystyn z Koziegłów, Jan Głowacza z Oleśnicy, Piotr Szafrańca, Sędziwój z Ostroroga, Wawrzyniec Zarembę, Mikołaj Białucha z Michałowa, Ścibor z Borysławic, Jan z Lichenia, Wojciech Malski, i Andrzej Ciołek z Żelechowa), jak też inne (starosta ruski Jan Mężyk z Dąbrowy, starosta ratneński i chełmski Jan Hryćko Kierdejowicz [jego obecność pod Łuckiem poświadcza dokument z 17 VIII 1431 r., ZDM VII, nr 2082], Spytek z Jarosławia, starosta sądecki Dziersław Włostowski, Piotr Niedźwiedzki czy sekretarz królewski Mikołaj Drzewicki, a także Jakub Nadobny z Rogowa, Jakub Ligęza, Paweł Zborzeński, Henryk Pakosławski, Sulisław Sieradzki, Mikołaj Słąka z Ławszowa [potem chorąży sandomierski 1435-1444 - UM, s. 169, 343], burgrabia chełmski Jan Ciołek z Unikowa, Stanisław Boruta z Konina i Mikołaja Parawa z Lubina); zob. Długosz, lib. XI-XII, s. 29, 30, 33, 34, 45 (osoby te kompletuje na podstawie narracji kronikarza G. B ła s z c z y k, Dzieje, t. II/1, s. 642), spośród możnych małopolskich, którzy wysłali Świdrygielle listy wypowiednie z Bystrzycy, w listach gwarantów obu rozejmów nie znalazł się tylko starosta lubelski Piotr Kurowski (D. W r ó b e 1, Przyczynek prozopograficzny, s. 242, 243, 245).

79 A. G ą s i o r o w s k i, Polscy gwaranci traktatów z krzyżakami XIV-XV wieku, Komunikaty Mazursko-Warmińskie 1971, nr 2-3, s. 251, 255-256. 
rozejm z 24 I 1411 r., również zawierany „w polu”80. Brak biskupów wynikał niewątpliwie z tej właśnie okoliczności. Nasze rozejmy zawierano w toku wołyńskich działań zbrojnych. Oba dokumenty sporządzono w obozie i od razu przekazano stronie litewskiej. Królowi pod Łuckiem nie towarzyszył wtedy chyba żaden biskup (może z wyjątkiem miejscowego Andrzeja? ${ }^{81}$ ). Biskup krakowski Zbigniew Oleśnicki wraz z wojskiem dotarł jedynie do Uściługu, skąd zawrócił wraz z podkanclerzym Władysławem Oporowskim ${ }^{82}$. Przy królu podczas zawierania obu rozejmów nie był również obecny biskup włocławski i kanclerz Królestwa Jan Szafraniec, który posłował wtedy do wielkiego mistrza Pawła von Rusdorfa (przybył do niego 31 lipca). Przypuszczano wprawdzie, że Jan udał się potem do Jagiełły pod Łuck, gdzie miał być już 17 sierpnia, aby poinformować władcę o krzyżackich przygotowaniach wojennych, opuścił jednak króla, aby zająć się obroną przed spodziewanym najazdem, a w otoczeniu Jagiełły pojawił się ponownie dopiero 8 września we Włodzimierzu ${ }^{83}$. Przekonanie o obecności biskupa Szafrańca w Łucku i Włodzimierzu wynika jednak z tego, że wystąpił on wspólnie z podkanclerzym Władysławem Oporowskim $\mathrm{w}$ formule datum per manus wystawionych tam wówczas dokumentów monarszych ${ }^{84}$. Nie są to jednak mocne przesłanki, ponieważ formuła ta odnosiła się do spisywania dokumentu, a zatem innego momentu niż jego actum $^{85}$. Przyjmując obecność Jana pod Łuckiem oraz we Włodzimierzu, należałoby przyjąć także obecność w sierpniu 1431 r. na Wołyniu podkanclerzego Władysława Oporowskiego, który wszakże, wedle relacji Długosza, opuścił króla w Uściługu. Pewniejsze wydaje się jednak, na co wskazuje absencja obu duchownych w dokumentach rozejmów łuckiego i czartoryskiego, w których wśród gwarantów nie ujęto kanclerza biskupa (co było niezgodne z przyjętą praktyką), że Jan Szafraniec i Władysław Oporowski nie znajdowali się wówczas w otoczeniu króla ${ }^{86}$.

Identyfikacja urzędniczego otoczenia Władysława Jagiełły podczas walk na Wołyniu pozwala na wysunięcie pewnych wniosków dotyczących procesu decyzyjnego, który doprowadził do zakończenia działań zbrojnych i zawarcia dwuletniego rozejmu. To bowiem wysocy urzędnicy ziemscy znajdujący się wówczas przy polskim monarsze stanowili jego „polową" radę i to na jej forum bez wątpienia dyskutowano w sierpniu 1431 r. o bieżących posunięciach politycznych oraz podejmowano konkretne decyzje. Ich personalna identyfikacja pozwala stwierdzić, że wśród obecnych pod Łuckiem wysokich i średnich urzędników ziemskich, centralnych i nadwornych przeważali dostojnicy wywodzący się z szerokiej Wielkopolski (województwo poznańskie,

${ }^{80}$ A. S z w e d a, Uwagi, s. 72-74.

81 Długosz podaje wprawdzie, że biskup łucki Andrzej przeniósł się z oblężonego Łucka do obozu królewskiego, a w drodze został ograbiony przez Polaków (Długosz, lib. XI-XII, s. 30), ale nie wiadomo, gdzie przebywał podczas pertraktacji rozejmowych.

${ }^{82}$ Długosz, lib. XI-XII, s. 26.

83 J. S p e rk a, Szafrańcowie, s. 207-208; A. S z w e da, Organizacja i technika dyplomacji polskiej w stosunkach z zakonem krzyżackim w Prusach w latach 1386-1454, Toruń 2009, s. 345-346.

${ }^{84}$ ZDM VII, nr 2082, 2083.

${ }^{85}$ Zob. I. S u łk ow s k a - K u r a s i ow a, Dokumenty królewskie, s. 111.

86 Tak Z. W i 1 k - W o ś, Władysław z Oporowa (ok. 1395-1453), podkanclerzy królewski, biskup włocławski i arcybiskup gnieźnieński, Studia Claromontana 21, 2003, s. 263-264. 
kaliskie, łęczyckie, sieradzkie, Kujawy i ziemia dobrzyńska). W komplecie widzimy wtedy wojewodów wielkopolskich (poznańskiego, kaliskiego, łęczyckiego, sieradzkiego, brzeskiego i inowrocławskiego), niemal wszystkich kasztelanów „większych” (poznańskiego, kaliskiego, gnieźnieńskiego, łęczyckiego, sieradzkiego, brzeskiego i dobrzyńskiego) i niektórych kasztelanów „mniejszych” (bydgoskiego, kruszwickiego i międzyrzeckiego $)^{87}$. Kontrastuje z tym nieco reprezentacja małopolska, składająca się z kasztelana krakowskiego, wojnickiego, sądeckiego, wiślickiego, bieckiego, połanieckiego, zawichojskiego, żarnowskiego oraz marszałków Królestwa i nadwornego. Warta podkreślenia wydaje się zwłaszcza absencja małopolskich wojewodów (krakowskiego i sandomierskiego) oraz kasztelana sandomierskiego. Wojewoda krakowski Jan z Tarnowa ruszył wprawdzie z królem na wojnę, ale z powodu choroby musiał zawrócić z drogi ${ }^{88}$. Familię Tarnowskich pod Łuckiem reprezentował jego młodszy brat, były starosta ruski Spytek z Tarnowa (Jarosławia), nieposiadający wówczas urzędu ziemskiego, który wszedł jednak w skład „rady wojennej” kierującej działaniami zbrojnymi w zastępstwie króla ${ }^{89}$. Na Wołyniu w sierpniu 1431 r. nie było także świeżo mianowanego wojewody sandomierskiego - Piotr Szafraniec (II) pełnił bowiem urząd starosty krakowskiego i pozostał w stolicy, natomiast pod Łuckiem walczył jego syn, podkomorzy krakowski Piotr (III) ${ }^{90}$. Najpewniej z powodu podeszłego wieku na wojnę nie ruszył kasztelan sandomierski Michał z Bogumiłowic, liczący wówczas przeszło 80 lat. Brak również źródeł, które poświadczyłyby uczestnictwo w wojnie łuckiej jego syna, starosty sandomierskiego Jana z Czyżowa ${ }^{91}$.

Niezależnie zatem od tego, kto wystąpił wobec króla z ideą zakończenia działań zbrojnych pod Łuckiem, to ostatecznie przyjęto ją na forum „polowej” rady królewskiej, w której większość wojewodów i kasztelanów stanowili Wielkopolanie. Warto też zwrócić uwagę, że negocjacje ze Świdrygiełłą, zarówno przed wkroczeniem wojsk na Wołyń, jak i tuż przed zawarciem rozejmu, prowadzili właśnie Wiekopolanie: wojewoda poznański Sędziwoj z Ostroroga, kasztelan łęczycki Wojciech Malski i kasztelan sieradzki Wawrzyniec Zaremba ${ }^{92}$. Wydaje się, że wojna nie cieszyła się ani wśród możnych wielkopolskich, ani u zwykłych pospolitaków zbytnią

87 Tak znacząca reprezentacja wysokich i średnich urzędników z obszaru szerokiej Wielkopolski pozwala odrzucić pojawiające się ostatnio sugestie o niewielkim uczestnictwie pospolitego ruszenia z tych ziem podczas działań na Wołyniu (W. Z a w i t k ow s k a, Walka polityczno-prawna o następstwo tronu po Władysławie Jagielle w latach 1424-1434, Rzeszów 2015, s. 274-276). Wojna z Litwą mogła być wśród Wielkopolan niezbyt popularna (zob. niżej), jednak spełnili oni obowiązek uczestnictwa w expeditio generalis.

${ }_{88}$ Długosz, lib. XI-XII, s. 26; W. D w o r z a c z e k, Leliwici Tarnowscy, s. 196. Rada składała się, obok Spytka, z księcia mazowieckiego Siemowita V, kasztelana krakowskiego Mikołaja Białuchy z Michałowa, wojewody poznańskiego Sędziwoja z Ostroroga, wojewody łęczyckiego Ścibora z Borysławic, wojewody brzeskiego Jana z Lichenia, marszałka koronnego Jana Głowacza z Oleśnicy, kasztelana łęczyckiego Wojciecha Malskiego, podkomorzego sandomierskiego Andrzeja Ciołka z Żelechowa oraz niesprawującego wówczas urzędów ziemskich Piotra Niedźwiedzkiego.

${ }^{89}$ Długosz, lib. XI-XII, s. 37; W. D w o r z a c z e k, Leliwici Tarnowscy, s. 132, 182, 229.

90 J. S p e rk a, Szafrańcowie, s. 204-207.

91 A. S o c h a c k a, Jan z Czyżowa namiestnik Władysława Warneńczyka. Kariera rodziny Półkozów w średniowieczu, wyd. 2, Oświęcim 2016, s. 16-21, 52, 88-93.

${ }_{92}$ Długosz, lib. XI-XII, s. 26, 28. 
popularnością. Wskazuje na to fakt, że wielkopolskie kontyngenty mocno spóźniły się na wyprawę, za co ich dowództwo król ostro zruga9 ${ }^{93}$. Dla terrigenów wielkopolskich, łęczyckich, sieradzkich, kujawskich i dobrzyńskich teatr działań wojennych na pewno był zbyt odległy, o czym przekonali się podczas nużącego długotrwałego przemarszu. Nie można również wykluczyć, że już w chwili rozpoczęcia działań zbrojnych na Wołyniu rycerze z zachodu i północy Polski mogli obawiać się rozpoczęcia działań przez sprzymierzonych ze Świdrygiełłą Krzyżaków. Nie jest natomiast możliwe, aby wpływ na zawarcie rozejmu miał sam fakt krzyżackich napadów na północną Wielkopolskę, Kujawy i ziemię dobrzyńską, te bowiem nastąpiły dopiero 28-29 sierpnia, a sam list wypowiedni wielkiego mistrza Pawła von Rusdorfa z datą 17 sierpnia został złożony na zamku dybowskim dopiero 26 sierpnia $^{94}$ - a więc tego samego dnia, kiedy uzgodniono rozejm czartoryski. Na stosunku do toczonej wojny odbijała się także niechęć samego króla do prowadzenia działań zbrojnych ${ }^{95}$. Nie można również wykluczyć ogólnie niejednoznacznego stosunku do konfliktu ze strony przynajmniej części z jego polskich uczestników. Oto bowiem przyszło im walczyć z Litwinami, z którymi wielu spośród nich jeszcze dziewięć lat wcześniej wspólnie gromiło Krzyżaków. Wypada wreszcie dodać, że polskie posiłki (chorągiew św. Jerzego) uczestniczyły także w wyprawie Witolda na Nowogród Wielki w 1428 r. Kombatanci tych bojów w sierpniu 1431 r. stanęli na Wołyniu przeciwko sobie $^{96}$. Niepopularność kampanii łuckiej wśród znacznej części polskiej szlachty potwierdza relacja Jana Długosza oraz inne przekazy, szeroko omówione ostatnio przez G. Błaszczyka ${ }^{97}$.

Interesujące są też pochodzące z drugiej ręki informacje (listy krzyżackich urzędników do wielkiego mistrza, wystosowane ze spotkania ze Świdrygiełłą w Grodnie z 1432 r.) o obwinianiu w Koronie za fiasko wyprawy wołyńskiej arcybiskupa Wojciecha Jastrzębca, Zbigniewa Oleśnickiego, wojewody sandomierskiego Piotra Szafrańca, podkomorzego dobrzyńskiego i sekretarza królewskiego Andrzeja Miłośnika z Lubina oraz Jana Taszki z Koniecpola ${ }^{98}$. Wydaje się jednak, że nie odpowiadały one w całości prawdzie, ponieważ spośród wymienionych brali w niej dowodny udział tylko Sędziwoj z Ostroroga i Jan Taszka. Co do pozostałych, to albo na pewno nie byli przy królu obecni (arcybiskup, Oleśnicki, wojewoda Szafraniec), albo przynajmniej brak pozytywnej informacji na ten temat (Andrzej z Lubina). W przypadku Taszki należy w dodatku poważnie wątpić, aby to on miał decydujący głos w sprawie zawarcie rozejmów (łuckiego i czartoryskiego), ze względu na niską pozycję w hierarchii decydentów. Z uwagą należy potraktować natomiast oskarżenia

93 Tamże, s. 27.

94 M. B is k u p, Wojny, s. 147.

95 Długosz, lib. XI-XII, s. 32, 46; G. B ł a s z c z y k, Dzieje, t. II/1, s. 642-643.

96 W wojnie z Nowogrodem (w której uczestniczył również Świdrygiełło) spośród polskich możnych obecnych w sierpniu i na początku 1431 r. na Wołyniu brali udział książę Kazimierz, Przybysław Dzik z Kadłuba, Jakub Przekora z Morawian i Wincenty Świdwa z Szamotuł, zob. Długosz, lib. XI, Varsoviae 2000, s. 246.

97 G. B ła s z c z y k, Dzieje, t. II/1, s. 642-643.

98 Codex epistolaris saeculi decimi quinti, t. III, dod., nr 10; W. Z a w i t k o w s k a, Jan Taszka, s. 133. 
kierowane wobec Sędziwoja z Ostroroga. Jeśli jednak to właśnie on odegrał istotną rolę podczas podejmowaniu decyzji o zakończeniu działań zbrojnych, to najpewniej, jako wojewoda poznański i cieszący się wielkim autorytetem lider polityczny szerokiej Wielkopolski, wyrażał on jedynie wolę innych wielkopolskich, łęczyckich, sieradzkich, kujawskich i dobrzyńskich wojewodów i kasztelanów z ,polowej” rady królewskiej.

\section{DOKUMENT}

W obozie pod Łuckiem, 20 VIII 1431 Król polski Władysław zawiera rozejm z księciem litewskim Bolesławem czyli Świdrygietta do 26 VIII $1431 \mathrm{r}$.

Oryg.: Москва, Российский государственный архив древних актов (РГАДА), p. 79 (Stosunki Rosji z Polska), on. 3, ed. xp. 1, k. 1, pergamin nierówno przycięty 426-409 × 322-315 mm, zakładka 405-409 × 62-67 mm (zob. fot. 1). Na odwrociu: 1. w prawej części, pismem tacińskim z końca XV lub początków XVI w., atrament jasnobrazowy: Littere Vladislai regis Polonie ac principis | Szwythrygayl, dum in campestralibus | erant, super treugis pacis servandis inter se mutuo datis; 2. w lewej części, skoropisem moskiewskim z XVII w.: Универсалъ короля полсого [sic] Влади|слава ко князом, бояром его, какъ | обозом стояль, указано всемъ, | какъ во обозе жить. Печати тие [sic] | городовъ и маршалковъ | (poniżej jedno slowo catkowicie zamazane tym samym atramentem); 3. pod nota 1 catkowicie zamazana i nieczytelna nota wykonana i zamazana tym samym atramentem co nota 2.

Do dokumentu na pergaminowych paskach przymocowanych $w$ poziomych wycięciach przywieszono 21 pieczęci: 1.-4. (rząd górny, pieczęć 1-4) pieczęć i pasek nie zachowaty się; 5. (rząd górny, pieczęć 5) okragła pieczęć Jana z Lichenia i Gosławic herbu Godziemba w zielonym wosku o średnicy $20 \mathrm{~mm}$ (oblamany fragment legendy), w uszkodzonej miseczce z naturalnego wosku o średnicy $39 \mathrm{~mm}$, legenda wykonana minuskuła gotyckq i ujęta $w$ dwie ciagte linie: $\mathrm{s}$ : iohannis : de : gos[lawycze] (uszkodzona część legendy rekonstruujemy na podstawie odcisku przy dokumencie króla Władystawa III dla wielkiego księcia Zygmunta Kiejstutowicza z 3 I 1433 r. (Akta unii, nr 58. rząd górny, pieczęć nr 7), w polu pieczęci herb Godziemba (zob. fot. 2); w 1422 r. Jan z Lichenia postużyt się inna pieczęcia (Dokumenty strony polsko-litewskiej pokoju metneńskiego z 1422 roku, wyd. P. Nowak, P. Pokora, Poznań 2004, s. 48, nr 38), a pod polskim dokumentem unii grodzieńskiej z 27 II 1434 r. przywiesit jeszcze innq o średnicy $23 \mathrm{~mm} z$ wykonana minuskuta gotycka legendą: $\mathrm{s} *$ iohannis * de * goslaw (Akta unii, nr 60, pieczęć nr 27); 6. (rząd górny, pieczęć 6) zachowat sie tylko pasek z resztkami miseczki z wosku naturalnego; 7.-8. (rzad górny, pieczęć 7-8) pieczęć i pasek nie zachowaty się; 9. (rząd górny, pieczęć 9) okragła pieczęć niezidentyfikowanego dysponenta herbu Odrowąz w zielonym wosku o średnicy $21 \mathrm{~mm}, w$ miseczce z wosku naturalnego o średnicy $42 \mathrm{~mm}$, legenda wykonana minuskuta gotycka i ujęta $w$ dwie ciagłe linie, częściowo nieczytelna: $+\mathrm{s}$ ioh[...]s de win[?]ols[...] (za konsultacje w zakresie odczytu legendy tej pieczęci autorzy pragna wyrazić głęboka wdzięczność Panu dr. hab. Marcinowi Hlebionkowi z Instytutu Historii i Archiwistyki UMK w Toruniu), w polu pieczęci herb Odroważ 
(zob. fot. 3); 10.-11. (rząd górny, pieczęć 10-11) pieczęć i pasek nie zachowaty się; 12. (rząd dolny, pieczęć 1) okragła pieczęć Jana Kretkowskiego (starszego) herbu Dołega w zielonym wosku o średnicy $28 \mathrm{~mm}, w$ miseczce z naturalnego wosku o nieregularnej średnicy 39-40 mm, legenda wykonana minuskuła gotycka i ujęta w dwie ciagte linie: $+*[\mathrm{~s} * \mathrm{i}]$ ohannis $* \mathrm{~d}(\mathrm{e})$ cretcow *, w polu pieczęci uszkodzona tarcza herbowa z nieczytelnym godłem; 13. (rzad dolny, pieczęć 2) zachowat się tylko pasek z resztkami miseczki z wosku naturalnego; 14. (rząd dolny, pieczęć 3) okragła pieczęć Marcina z Kalinowej herbu Zaremba w zielonym wosku o średnicy $24 \mathrm{~mm}$, w uszkodzonej miseczce z naturalnego wosku o średnicy $41 \mathrm{~mm}$ (nie zachowat sie fragment na lewo od paska), legenda wykonana minuskuła gotycka $i$ ujęta $w$ dwie ciagłe linie: + s : martinus : de : kalinowa, w polu pieczęci herb Zaremba (publikacja: Dokumenty strony polsko-litewskiej, s. 40-41, 62-63, nr 27 i 61, tam podane téz inne zachowane odciski pieczęci z lat 1422-1433); 15. (rząd dolny, pieczęć 4) pieczęć i pasek nie zachowaty się; 16. (rząd dolny, pieczęć 5) okragła pieczęć Jana Głowacza z Oleśnicy herbu Dębno w zielonym wosku o średnicy $25 \mathrm{~mm}, w$ nieregularnej miseczce z wosku naturalnego o średnicy 40-44 mm, legenda wykonana minuskuła gotycka i ujęta w jedna zewnętrzna ciagła linię oraz druga, wewnętrzna, składajaca się z trzech łuków gotyckich, w końcowej partii nieco zagnieciona: $+\mathrm{s}$ : iohannis * de * oleschnicia * marsalci (zagnieciona końcowa partię legendy odtwarzamy $w$ oparciu o jej odczyt z odcisku przywieszonego do dokumentu króla Władysława III dla wielkiego księcia Zygmunta Kiejstutowicza z 3 I 1433 r. [Akta unii, $n r$ 58, rząd dolny, pieczęć $n r$ 14]), w polu tarczy herb Dębno (zob. fot. 4); 17. (rzad dolny, pieczęć 6) okragła pieczęć Wawrzyńca Zaremby z Kalinowej herbu Zaremba $w$ zielonym wosku o średnicy $24 \mathrm{~mm}, w$ nieregularnej miseczce $z$ wosku naturalnego o średnicy 37-42 mm, legenda wykonana minuskuła gotycka $i$ ujęta $w$ dwie ciagte linie: * $\mathrm{s} *$ zarambe * de calinowa, w polu pieczęci herb Zaremba; ta sama pieczęć przywieszona do dokumentu króla Władysława III dla wielkiego księcia Zygmunta Kiejstutowicza z 3 I 1433 r. (Akta unii, nr 58, rząd górny pieczęć nr 10); 18. (rząd dolny, pieczęć 7) pieczęć i pasek nie zachowaty się; 19. (rzad dolny, pieczęć 8) okragła pieczęć kasztelana sądeckiego Krystyna z Koziegłów herbu Lis w zielonym wosku o średnicy $27 \mathrm{~mm}$, w nieregularnej miseczce z wosku naturalnego o średnicy 40-42 mm, legenda wykonana minuskuła gotycka i ujęta $w$ dwie ciagłe linie: * $\mathrm{s}+\operatorname{cri}(s)$ tani sando $\mathrm{m}$ [?] cozegl(owy) w polu pieczęci nieco zagnieciony herb Lis (zob. fot. 5), za pomoc w odczycie legendy pragniemy wyrazić wdzięczność Panu dr. hab. Marcinowi Hlebionkowi; ta sama pieczęć została przywieszona do polskiego dokumentu traktatu brzeskiego z 31 XII 1435 r., opieczętowanemu na zjeździe w Sieradzu 4 III 1436 r. (Deutschordens-Zentralarchiv Wien, Urkunden, nr 3359); 20. (rząd dolny, pieczęć 9) okrągła pieczęć w zielonym wosku nieznanego dysponenta o średnicy 24 mm, w miseczce z naturalnego wosku o średnicy 39 mm, legenda wykonana minuskuła gotycka i ujęta $w$ dwie ciagłe linie, $w$ znacznym stopniu uszkodzona: + s ... de ...; 21. (rzad dolny, pieczęć 10) okragła pieczęć Wojciecha z Bnina $w$ zielonym wosku o średnicy $22 \mathrm{~mm}$, w nieregularnej miseczce $z$ wosku naturalnego o średnicy 39-43 mm, legenda wykonana minuskuła gotycka $i$ ujęta $w$ dwie ciagłe linie: $+[\mathrm{s}] *$ alberti * de * bonyn, w polu tarczy herb Łodzia (zob. fot. 6); pieczęć została przywieszona przez kasztelana gnieźnieńskiego Piotra z Bnina herbu Łodzia, 
który użyt jej także przy dokumencie króla Władysława III dla wielkiego księcia Zygmunta Kiejstutowicza z 3 I 1433 oraz polskiego dokumentu unii grodzieńskiej z 27 II 1434 r. (Akta unii, nr 58, rząd górny, pieczęć 9; nr 60, pieczęć 45); Piotr postużyt się zapewne pieczęcia swojego brata Wojciecha, który zmart ok. 1419 r., watpliwe, aby była to pieczęć bratanka Piotra, młodszego Wojciecha (syna Mikołaja z Bnina), ponieważ ten byt chyba jeszcze zbyt mlody, aby udać się na wyprawę tucka (o rodzinie tej zob. W. Brzeziński, Koligacje, s. 328-333).

Кор.: 1. РГАДА ф. 79, оп. 3, ед. хр. 1, k. 2-3v. - kop. N. N. Bantysza-Kamienskiego, dołaczony rosyjski przektad (k. 4-7v) i jego brudnopis (k. 8-9v); 2. Архив Санкт-Петербургского Института истории Российской академии наук, ф. 276 (Издательский архив Ленинградского отделения Института истории AH CCCP), д. 57, № 2, k. 6-10v, dotaczony rosyjski przektad uwierzytelniony przez księcia Michaiła Obolenskiego.

Reg.: 1. Отдел рукописей Российской государственной библиотеки, $\phi .68$ (Генеральный штаб), ед. хр. 301: Реестр договорам и грамотам европейских и азиатских дворов (1431-1724), № 1, k. 1, wykaz przepisany 23 VI 1813 r. przez pisarza Iwana Żdanowskiego i uwierzytelniony przez rzeczywistego radce dworu N. N. Bantysza-Kamenskiego; 2. I. Daniłowicz, Skarbiec diplomatów papieskich, cesarskich, królewskich, ksiązęcych, uchwat narodowych, postanowień różnych władz i urzędów postugujacych do krytycznego wyjaśnienia dziejów Litwy, Rusi Litewskiej $i$ ościennych im krajów, t. II, wyd. J. Sidorowicz, Wilno 1862, nr 1561; 3. Index actorum saeculi XV ad res publicas Poloniae spectantium, wyd. A. Lewicki, Kraków 1888, nr 1698; 4. Н. Н. Бантыши-Каменский, Обзор внешних сношений России (по 1800 год), ч. 3, Москва 1897, s. 75; 5. Опись архива Посольского приказа 1673 года, подг. В. И. Гальиов, ред. С. О. Шмидт, ч. I, Москва 1990, s. 227, k. 463v, tekst bardzo podobny do rosyjskojęzycznej noty dorsalnej: „, Уневерсал польского Владислава короля ко князем, бояром ево, как обозом стоял, указано всем как жить в обозе, внизу 20 печатей"; б. Центральный государственный архив древних актов СССР. Путеводитель, ч. 1, ред. С. К. Богоявленский, Москва 1946, s. 34; 7. Обзор документальных материалов Центрального государственного архива древних актов по истории СССР периода феодализма XI-XVI вв., сост. В. Н. Шумилов, ред. М. Н. Тихомиров, Москва 1954, s. 32; 8. Центральный государственный архив древних актов СССР. Путеводитель в 4 томах, m. I, Москва 1991, s. 298.

Uwaga: Tekst dokumentu wydany wedhug zasad A. Wolffa, Projekt instrukcji wydawniczej dla pisanych źródet historycznych do polowy XVI wieku, Studia Źródtoznawcze 1, 1957, s. 151-181.

Dokument zostat odrestaurowany w 1989 r. we Wszechzwiazkowym Instytucie Naukowo-Badawczym Restauracji w Moskwie (Всесоюзный научно-исследовательский институт реставрации).

${ }^{a}$ Wladislaus Dei gracia $\|r\|$ ex $\|\mathrm{P}\|$ olonie $\|\mathrm{L}\| y$ thwanieque princeps suppremus et $\|$ hleres $\|\mathrm{R}\|$ ussie etc., $\|$ sllignificamus tenore presencium, quibus expedit, I universis, quomodo cupientes bellorum evitare disturbia et humani sangwinis, prout mentis nostre semper fuit ${ }^{b}$, profluvia summovere ac differencias, controlversias, displicencias, discusiones, 
rancores et odia inter nos, principes, prelatos, barones et subditos Regni nostri Polonie nobisque adherentes ab una $\mid$ ac preclarum principem dominum Boleslaum alias Swydrigal ducem Lythwanie, fratrem nostrum necnon duces, boyaros, nobiles et subditos Magni Ducatus terrarum Lythwanie et Russie ipsisque adherentes parte ab altera, suscitatas et exortas per modum amicabilis concordie complanare et sopire ac ad unionis pacis sincere et perfecte statum reducere, a die date presencium usque ad diem dominicum proximum [26 VIII 1431] cum prefato duce Swydrigal suisque adherentibus et terris supradictis Magni Ducatus Lythwanie treugas pacis munimus et fecimus presentibusque facimus et firmamus, quibus quidem treugis durantibus predictus dux Swydrigal, frater noster, pro conferendis nobiscum et consiliariis nostris presencialiter super huiusmodi displicenciis et iniuriis feria quinta proxima [23 VIII 1431] in loco exercituum nostrorum vel de prope ipsos, ubi ei placuerit, ex hiis eligendum, de quo consiliarii utriusque nostrum comodose inter nos utrimque deambulare negocia nostra comportantes, debet personaliter cum consiliariis eius constitui et venire, cui cum ducibus, boyaris, comittiva, rebus, personis et equis, quos secum habuerit, salwum, securum, cristianicum et indubitatum conductum ad nos et exercitus nostros vel ad locum prope ipsos, ut prefertur, veniendi, standi, morandi nobiscumque et consiliariis nostris per se vel mediantibus suis consiliariis predictis, super pace et concordia tractandi, practicandi, placitandi et de ipsa pace concludendi ac ad propria viceversa nobiscum et consiliariis nostris facta conclusione super pace huiusmodi vel non facta salwis rebus et personis absque offensa et molestia quibuscumque redeundi damus, concedimus et tenore presencium largimur, pollicentes ac promittentes verbo nostro regio sub fide et honore ac onere iuramenti huiusmodi salwum conductum nostrum prefato duci Swydrigal fratri nostro et comittive ipsius integre et inviolabiliter, absque dolo et fraude ac ingeniis et coloribus quibusvis exquisitis et exquirendis tenere et observare, illo tamen addito specialiter et expresso, quod mox et absque more dispendio uterque nostrum debebit huiusmodi treugas pacis taliter inter nos firmatas, prorogatas et receptas suis gentibus armigeris ubicumque existentibus pura fide significare, insinuare et intimare, ipsis seriose et firmiter iniungendo, ut se invicem treugis huiusmodi pendentibus hostiliter non invadant, nec aliqua dampna sibi hincinde faciant vel inferant, isto specialiter desumpto et excluso, quod si armigeri nostri, quos sabbato proxime preterito [18 VIII 1431] ad propellendum et fugandum hostes nobis et exercitibus nostris nocere machinantes in notabili direximus comittiva, cum eisdem hostibus conflixerint aut ipsis quoquomodo nocuerint, de treuga huiusmodi nondum informati, nolumus ipsis treugis per hoc derogare, hoc eciam adiuncto, quod eisdem treugis pendentibus licitum sit nobis et exercituum nostrorum hominibus et gentibus frumenta, gramina et alia quecumque equorum pabula et necessaria libere et absque omni resistendi partis adverse ac invasione nostrorum recipere eisdemque utifrui secure, demptis hominibus, pecudibus et pecoribus, piscaturas quoque liberas in aquis singulis absque quovis impedimento facere possumus et habere, ita tamen, quod rupturas piscinarum infra treugas pacis predictas fieri prohibere debemus. Isto eciam specialiter expresso et incluso, quod castrum Luceriense ${ }^{l}$ et ipsius defensores ac in eo existentes treugis predictis volumus esse inclusos ipsisque frui, uti et gaudere ita tamen, quod eisdem durantibus treugis nullus et nulla hominum extra castrum predictum ${ }^{c}$ in eodem habitancium exire 
debeant, nec ligna, gramina, aquam et quecumque pabula aut qualiacumque necessaria, quocumque ingenio oculte vel aperte ad castrum Luceriense predictum procurare aut portare debebunt, si autem hiis in contrarium per quempiam foret attemptatum, per hoc non derogabitur ipsis treugis et conductui predictis neque infringentur, sed unusquisque delinquens ipsas violando pro excessu suo punietur. Et predictus eciam frater noster literas reversales et reciprocas similes in tenore presencium sigillo suo necnon ducum et boyarorum terrarum prefati Magni Ducatus pociorum etcondicione eminenciorum sigillis comunitas et roboratas pari quantitate sigillorum nobis dare et destinare quanto celerius poterit tenebitur et debebit. Harum quibus sigillum nostrum et preclari principis domini Semowiti ducis Mazowie nepotis nostri carissimi ${ }^{2}$ necnon magnificorum, strenuorum et nobilium Nicolai de Mychalow castellani Cracoviensis ${ }^{3}$, Sandiwogii de Ostrorog Poznaniensis ${ }^{4}$, Andree de Domaborze Calisiensis ${ }^{5}$, Martini de Calinowa Siradiensis ${ }^{6}$, Cztiborii de Borzislawycze Lanciciensis ${ }^{7}$, Jerandi de Brudzow Wladislawiensis ${ }^{8}$, Johannis de Lichin Brzestensis ${ }^{9}$ pallatinorum, Martini de Slawsko Poznaniensis ${ }^{10}$, Petri de Bnyn Gneznensis ${ }^{11}$, Petri de Zyrniki Calisiensis ${ }^{12}$, Laurencii Zaramba Syradiensis ${ }^{13}$, Alberti Malski Lanciciensis ${ }^{14}$, Dobeslai Woyniczensis ${ }^{15}$, Cristini Sandeczensis ${ }^{16}$, Cristini Brzestensis ${ }^{17}$, Johannis Dobrinensis ${ }^{18}$ castellanorum et Johannis Glowacz de Oleschnicza Regni Polonie marsalci ${ }^{19}$, sincere nobis dilectorum, hoc ipsum pro nobis promittentes, sigilla sunt appensa testimonio literarum. Datum in loco stacionis nostre campestris exercitus feria secunda ante festum sancti Bartholomei anno Domini millesimo etc. tricesimo primo. Premissa itaque omnia et singula tam pro nobis, quam subditis et adherentibus nobis et Regno nostro universis bona fide et intemerata, ut supra, tenere et inviolabiliter observare promittimus et spondemus.

Dominus rex per se

${ }^{a}$ Inicjat wysokości ok. 11 wersów Oryg., $\quad{ }^{b}$ do tego miejsca atrament wyblakty i tekst słabo czytelny, $\quad$ c po wyrazie nastepuja dwie wyskrobane litery, zapewne eo.

${ }^{1}$ Zamek w Łucku, głównym mieście Wołynia, obecnie na Ukrainie, siedziba obwodu wołyńskiego i rejonu tuckiego.

${ }^{2}$ Siemowit V, książę z mazowieckiej linii Piastów, książę rawski, gostyniński i sochaczewski, syn księcia płockiego Siemowita IV i Aleksandry Olgierdówny, siostrzeniec króla Władysława Jagietly, ur. 1388/1389, zm. 1442 (A. Supruniuk, Siemowit V, w: PSB XXXVII, s. 81-84).

${ }^{3}$ Mikołaj Białucha z Michałowa herbu Poraj (Róża), kasztelan wojnicki 1399-1410, wojewoda sandomierski 1410-1430, kasztelan krakowski 1430-1438 (A. Kamiński, Mikołaj z Michałowa i Kurozwęk zw. Biatucha, w: PSB XXI, s. 123-126; ULS, s. 137, 175; UM, s. 67, 226, 256, 288, 301, 345).

${ }^{4}$ Sędziwoj z Ostroroga herbu Nałęcz, wojewoda poznański 1406-1441, starosta generalny Wielkopolski 1411-1415, 1419-1426, 1432-1434 (A. Gąsiorowski, Ostroróg Sędziwój, w: PSB XXIV, s. 519-523; UKD, s. 214, 240; UW, s. 139, 156, 172-173, 194).

${ }^{5}$ Andrzej z Danaborza herbu Pałuka, kasztelan kamieński 1424-1427, wojewoda kaliski 14271435, starosta nakielski 1429-1435 (UW, s. 116, 126, 128, 182; W. Brzeziński, Koligacje matżeńskie możnowładztwa wielkopolskiego $w$ drugiej połowie XIV i pierwszej połowie XV wieku, Wrocław 2012, s. 345-346).

${ }^{6}$ Marcin Zaremba z Kalinowej herbu Zaremba, kasztelan sieradzki 1399-1430, wojewoda sieradzki 1430-1437 (A. Gąsiorowski, Marcin Zaremba z Kalinowy, w: PSB XIX, s. 564-565; UtS, s. 101, 106, 129, 156, 170). 
${ }^{7}$ Ścibor z Borysławic, Łubnicy herbu Jastrzębiec, bratanek arcybiskupa gnieźnieńskiego Wojciecha Jastrzębca, wojewoda tęczycki 1428-1435 (UtS, s. 71, 83, 174; B. Czwojdrak, Jastrzębce $w$ ziemi krakowskiej i sandomierskiej do połowy XV wieku, Kraków 2007, s. 112-126).

${ }^{8}$ Jarand z Grabia, Dąbrówki, Brudzewa herbu Pomian, wojewoda inowrocławski 1426-1438, wojewoda sieradzki 1439-1452 (UKD, s. 93, 160, 209, 227, 233; UtS, s. 129, 161; S. Szybkowski, Kujawska szlachta, s. 578-580).

${ }^{9}$ Jan z Lichenia, Gostawic herbu Godziemba, kasztelan śremski 1422-1430, wojewoda brzeski 1430-1448 (A. Gąsiorowski, Licheński Jan, w: PSB XVII, s. 294-295; UKD, s. 192, 214, 237; UW, s. 109, 163, 190).

${ }^{10}$ Marcin ze Stawska herbu Zaremba, kasztelan kaliski 1426-1428, kasztelan poznański 14281436, wojewoda kaliski 1436-1453, opiekadlnik Wielkopolski 1434-1438, starosta generalny Wielkopolski 1428-1430 (A. Gasiorowski, Marcin ze Stawska, w: PSB XIX, s. 572; UW, s. 111, 126, 142, 147, 151, 173, 198).

${ }^{11}$ Piotr z Bnina herbu Łodzia, kasztelan gnieźnieński 1428-1448 (A. Gąsiorowski, Piotr z Bnina, w: PSB XXVII, s. 385; UW, s. 104, 180).

${ }^{12}$ Piotr z Żernik herbu Dryja, kasztelan kaliski 1428-1445 (A. Gąsiorowski, Piotr z Żernik, w: PSB XXVII, s. 440; UW, s. 107, 111, 203).

${ }^{13}$ Wawrzyniec Zaremba z Kalinowej herbu Zaremba, marszatek nadworny 1420-1426, marszałek Królestwa 1426-1430, kasztelan sieradzki 1430-1452, wojewoda sieradzki 1453 (UC, s. 78, 83, 217; UtS, s. 106, 129, 153, 156, 170; A. Szymczakowa, Szlachta, s. 95-102).

${ }^{14}$ Wojciech Malski herbu Nałęcz, kasztelan tęczycki 1430-1436, wojewoda łęczycki 1436-1453, wojewoda sieradzki 1454, namiestnik króla w Wielkopolsce 1440-1447, starosta generalny Wielkopolski 1443-1447 (K. G. Latocha, Wojciech Malski (ok. 1380-1454)-wojewoda łęczycki i sieradzki oraz namiestnik królewski na Wielkopolskę, Warszawa 2015).

${ }^{15}$ Dobiestaw z Oleśnicy, Sienna herbu Dębno, kasztelan wojnicki 1411-1433, kasztelan lubelski 1433-1435, kasztelan sandomierski 1435-1438, wojewoda sandomierski 1438-1440 (F. Kiryk, Oleśnicki Dobiesław, w: PSB XXIII, s. 762-763; UM, s. 140, 177, 227, 256-257, 288, 351).

${ }^{16}$ Krystyn z Koziegłów herbu Lis, kasztelan sadecki 1419-1437 (UM, s. 236, 240, 340; B. Śliwiński, Lisowie Krzelowscy w XIV-XV w. i ich antenaci. Studium genealogiczne, Gdańsk 1993, s. 95-105).

${ }^{17}$ Krystyn ze Smólska herbu Szeliga, kasztelan kruszwicki 1411-1430, kasztelan brzeski 14301434 (UKD, s. 116, 174, 182; S. Szybkowski, Kujawska szlachta, s. 588-589).

18 Jan Kretkowski herbu Dołęga, kasztelan rypiński 1418-1428, kasztelan dobrzyński 1429-1433 (UM, s. 300, 340; UKD, s. 142-143, 164, 224-225, 237; T. Stawiński, Kretkowscy $i$ ich dzieje od połowy XIV wieku, wyd. 2, Warszawa-Skrzeszew 2011, s. 36-51, 81-83, 543-544).

${ }^{19}$ Jan Głowacz z Oleśnicy herbu Dębno, kasztelan żarnowski 1425-1430, marszałek Królestwa 1430-1440, kasztelan sandomierski 1440-1442, wojewoda sandomierski 1442-1460 (M. Koczerska, Oleśnicki Jan zw. Głowacz, w: PSB XXIII, s. 764-766; Urzędnicy centralni, s. 78, 190; UM, s. 178, 227, 264, 288, 315, 351).

\section{BIBLIOGRAFIA}

Adamus J., Kodeks dyplomatyczny Litwy, Ateneum Wileńskie 8, 1931-1932.

Adamus J., W sprawie kodeksu dyplomatycznego Litwy, Sprawozdania Towarzystwa Naukowego we Lwowie 12, 1932, z. 3.

Adamus J., Wydawnictwa źródeł do historii Litwy, w: Pamiętnik VI Powszechnego Zjazdu Historyków Polskich w Wilnie 17-20 września 1935 r., t. I, Lwów 1935.

Bar P., Der „Krönungssturm“: König Sigismund von Luxemburg, Grossfürst Witold von Litauen und das gescheiterte politische Bündnis. Mit einem Quellenanhang, Roczniki Historyczne 83, 2017.

Bieniak J., Mikołaj z Warzymowa, w: Polski słownik biograficzny, t. XXI (1976). 
Biskup M., Najazd krzyżacki na Polskę i bitwa pod Dąbkami 1431 r., w: Studia historyczne. Stanisławowi Herbstowi na sześćdziesięciolecie urodzin w upominku uczniowie, koledzy, przyjaciele, Warszawa 1967.

Biskup M., Wojny Polski z Zakonem Krzyżackim (1308-1521), Gdańsk 1993.

Błaszczyk G., Burza koronacyjna. Dramatyczny fragment stosunków polsko-litewskich w XV wieku, Poznań 1998.

Błaszczyk G., Dzieje stosunków polsko-litewskich, t. II, cz. 1, Poznań 2007.

Brzeziński W., Koligacje małżeńskie możnowładztwa wielkopolskiego w drugiej połowie XIV i pierwszej połowie XV wieku, Wrocław 2012.

Burgrabiowie zamku krakowskiego XIII-XV wieku. Spisy, Kórnik 1999.

Czwojdrak B., Zofia Holszańska. Studium o dworze i roli królowej w późnośredniowiecznej Polsce, Warszawa 2012.

Czwojdrak B., Rogowscy herbu Działosza - podskarbiowie królewscy. Studium z dziejów możnowładztwa w drugiej połowie XIV i w XV wieku, Katowice 2002.

Czwojdrak B., Jastrzębce w ziemi krakowskiej i sandomierskiej do połowy XV wieku, Kraków 2007.

Dembiński P., Poznańska kapituła katedralna schyłku wieków średnich. Studium prozopograficzne 1428-1500, Poznań 2012.

Dücker J., Sigismund und der Konflikt um die Königskrönung Witolds von Litauen (1429/30), w: Emperor Sigismund and the Orthodox World, Wien 2010.

Dworzaczek W., Leliwici Tarnowscy. Z dziejów możnowładztwa małopolskiego wiek XIV-XV, Warszawa 1971.

Gąsiorowski A., Itinerarium króla Władysława Jagiełły 1386-1434, Warszawa 1972, wyd. 2, Warszawa 2015.

Gąsiorowski A., Korzbok Piotr, w: Polski słownik biograficzny, t. XIV (1968-1969).

Gąsiorowski A., Licheński Jan, w: Polski słownik biograficzny, t. XVII (1972).

Gąsiorowski A., Marcin Zaremba z Kalinowy, w: Polski słownik biograficzny, t. XIX (1974).

Gąsiorowski A., Marcin ze Sławska, w: Polski słownik biograficzny, t. XIX (1974).

Gąsiorowski A., Ostroróg Sędziwój, w: Polski słownik biograficzny, t. XXIV (1979).

Gąsiorowski A., Piotr z Bnina, w: Polski słownik biograficzny, t. XXVII (1981).

Gąsiorowski A., Piotr z Żernik, w: Polski słownik biograficzny, t. XXVII (1981).

Gąsiorowski A., Polscy gwaranci traktatów z krzyżakami XIV-XV wieku, Komunikaty Mazursko-Warmińskie 1971, nr 2-3.

Jakubowski J., Archiwum państwowe W. X. Litewskiego i jego losy, Archeion 9, 1931.

Jasiński K., Rodowód Piastów mazowieckich, Poznań-Wrocław 1998 (recte: 2009).

Jurek T., Szamotulski Dobrogost Świdwa, w: Polski słownik biograficzny, t. XLVI (2009-2010).

Jurek T., Szamotulski Wincenty Świdwa, w: Polski słownik biograficzny, t. XLVI (2009-2010).

Kamiński A., Mikołaj z Michałowa i Kurozwęk zw. Białucha, w: Polski słownik biograficzny, t. XXI (1976).

Kiryk F., Oleśnicki Dobiesław, w: Polski słownik biograficzny, t. XXIII (1978).

Kiryk F., Przekora Jakub, w: Polski słownik biograficzny, t. XXVIII (1984-1985).

Koczerska M., Oleśnicki Jan zw. Głowacz, w: Polski słownik biograficzny, t. XXIII (1978).

Kotzebue A. von, Preussens aeltere Geschichte, t. III, Riga 1808.

Kurtyka J., Podole w średniowieczu i okresie nowożytnym: obrotowe przedmurze na pograniczu cywilizacji, w: tenże, Podole w czasach jagiellońskich, Kraków 2011.

Krzyżaniakowa J., Kancelaria królewska Władysława Jagiełły. Studium z dziejów kultury politycznej w XV wieku, cz. 2: Urzędnicy, Poznań 1979.

Lewicki A., Powstanie Świdrygiełły. Ustęp z dziejów unii Litwy z Koroną, Kraków 1892.

Michajlovs `kij V., Podole po Grunwaldzie (1410-1430): walka Witolda z Jagiełłą, w: Jogailos ir Vytauto laikai. Mokslinių straipsnių rinkinys, skirtas Žalgirio mūšio 600-osioms metinems, Kaunas 2011.

Możejko B., Szybkowski S., Śliwiński B., Zawisza Czarny z Garbowa herbu Sulima, Gdańsk 2003. 
Nikodem J., Stosunki Świdrygiełły z Zakonem Krzyżackim w latach 1430-1432, Białoruskie Zeszyty Historyczne 14, 2000.

Nikodem J., Witold, wielki książę litewski (1354 lub 1355 - 27 października 1430 roku), Kraków 2013.

Nikodem J., Wyniesienie Świdrygiełły na Wielkie Księstwo Litewskie, Białoruskie Zeszyty Historyczne 19, 2003.

Nowak T., Własność ziemska w ziemi łęczyckiej w czasach Władysława Jagiełły, Łódź 2003.

Osiński K., Przejęcie stolca wielkoksiążęcego przez Świdrygiełłę. Próba rekonstrukcji wydarzeń do końca 1430 roku, Białoruskie Zeszyty Historyczne 43, 2015.

Osiński K., Rządy wielkoksiążęce Świdrygiełly w latach 1430-1432, Białoruskie Zeszyty Historyczne 45, 2016.

Petrauskas R., Korona Witolda: niedoszła koronacja i jej późniejsza legenda historyczna, w: Tradycja-metody przekazywania i formy upamiętniania w państwie polsko-litewskim, XV - pierwsza połowa XIX wieku, Warszawa 2011.

Poniewozik L., Prałaci i kanonicy sandomierscy w okresie średniowiecza, Toruń 2004.

Rozbiór krytyczny Annalium Poloniae Jana Długosza z lat 1385-1444, t. 1, Wrocław 1961.

Semkowicz W., Koreferat, w: Pamiętnik VI Powszechnego Zjazdu Historyków Polskich w Wilnie 17-20 września 1935 r., t. II, Lwów 1936.

Sławiński T., Kretkowscy i ich dzieje od połowy XIV wieku, wyd. 2, Warszawa-Skrzeszew 2011.

Sochacka A., Jan z Czyżowa namiestnik Władysława Warneńczyka. Kariera rodziny Półkozów w średniowieczu, wyd. 2, Oświęcim 2016.

Sperka J., Szafraniec Piotr (zm. 1441), w: Polski słownik biograficzny, t. XLVI (2009-2010).

Stolarczyk T., Świdrygiełło przeciwko Jagielle - tzw. wojna łucka w 1431 r., Mars 10, 2001.

Sułkowska-Kurasiowa I., Dokumenty królewskie i ich funkcje w państwie polskim za Andegawenów i pierwszych Jagiellonów 1370-1444, Warszawa 1977.

Supruniuk A., Siemowit V, w: Polski słownik biograficzny, t. XXXVII (1996-1997).

Szczur S., Paweł zw. Złodziej, w: Polski słownik biograficzny, t. XXV (1980).

Szweda A., Organizacja i technika dyplomacji polskiej w stosunkach z zakonem krzyżackim w Prusach w latach 1386-1454, Torun 2009.

Szweda A., Uwagi o dokumentach rozejmowych i pokojowych z okresu wojny 1409-1411, Zapiski Historyczne 75, 2010, z. 2.

Szybkowski S., Jagiełło, Witold, Zofia Holszańska i polityka dynastyczna, Średniowiecze Polskie i Powszechne 8 (12), 2016.

Szybkowski S., Kujawska szlachta urzędnicza w późnym średniowieczu (1370-1501), Gdańsk 2006.

Szymczakowa A., „Nobiles Siradienses”. Rody Porajów, Pomianów, Gryfów, Kopaczów i Pobogów, Warszawa 2011.

Szymczakowa A., Szlachta sieradzka w XV wieku. „Magnifici et generosi”, Łódź 1998.

Śliwiński B., Lisowie Krzelowscy w XIV-XV w. i ich antenaci. Studium genealogiczne, Gdańsk 1993.

Šenavičienė I., Ignoto Danilavičiaus raportas apie kelionę ị Maskvą ir Peterburgą (1818 m.), Lietuvos istorijos metraštis 1998.

Urzędnicy centralni i nadworni Polski XIV-XVIII wieku. Spisy, Kórnik 1992

Urzędnicy kujawscy i dobrzyńscy XII-XV wieku. Spisy, Kórnik 2014

Urzędnicy łęczyccy, sieradzcy i wieluńscy XIII-XV wieku. Spisy, Wrocław 1985

Urzędnicy małopolscy XII-XV wieku. Spisy, Wrocław 1990

Urzędnicy podolscy XIV-XVIII wieku. Spisy, Kórnik 1998

Urzędnicy województwa ruskiego XIV-XVIII wieku (ziemie halicka, lwowska, przemyska, sanocka). Spisy, opr. K. Przyboś, Wrocław 1987

Urzędnicy wielkopolscy XII-XV wieku. Spisy, Wrocław 1985

Uzupełnienia do spisów urzędników małopolskich XII-XVIII wieku, w: Burgrabiowie zamku krakowskiego XIII-XV wieku. Spisy, Kórnik 1999 
Wilk-Woś Z., Władysław z Oporowa (ok. 1395-1453), podkanclerzy królewski, biskup włocławski i arcybiskup gnieźnieński, Studia Claromontana 21, 2003.

Wroniszewski J., „Nobiles Sandomierienses”. Rody Dębnów, Janinów, Grzymałów, Doliwów i Powałów, Kraków 2013.

Wroniszewski J., Ród Rawiczów. Warszowice i Grotowice, Toruń 1992.

Wróbel D., Elity polityczne Królestwa Polskiego wobec problemu krzyżackiego w czasach Władysława Jagiełły, Lublin 2016.

Wróbel D., Przyczynek prozopograficzny do dziejów tzw. wyprawy łuckiej z 1431 r., Res Historica 41, 2016.

Zawitkowska W., W służbie pierwszych Jagiellonów. Życie i działalność kanclerza Jana Taszki Koniecpolskiego, Kraków 2005.

Zawitkowska W., Walka polityczno-prawna o następstwo tronu po Władysławie Jagielle w latach 1424-1434, Rzeszów 2015.

Белокуров С. А., Московский архив Министерства иностранных дел в 1812 году, Москва 1913.

Бучинський Б., Кілька причинків до часів вел. князя Свитригайла (1430-1433), Записки наукового товариства ім. Шевченка 76, 1907.

Государственный архив России XVI столетия: Опыт реконструкции, подг. А. А. Зимин, ред. Л. В. Черепнин, вып. 1-3, Москва 1978.

Долгова С. Р., Г. Ф. Миллер и Московский архив Коллегии иностранных дел 1766-1783 гг., Исторический архив 2006, nr 1.

Дремина Г. А., Из истории Центрального государственного архива древних актов СССР, Москва 1959.

Кучкин В. А., Договорные грамоты московских князей XIV века. Внешнеполитические договоры, Москва 2003.

Михайловський В., Еластична спільнота. Подільська шляхта в другій половині XIV 70-х роках XVI століття, Київ 2012.

Полехов С. В., Наследники Витовта. Династическая война в Великом княжестве Литовском в 30-е годы XV века, Москва 2015.

Полянская Э. Л., „Угнетённая войной и опустошённая огнём” или Свидригайло против Ягайло в борьбе за Волынскую землю в освещении Яна Длугоша и польской историографии, w: Colloquia Russica, ser. I, t. II: Principalities in Lands of Galicia and Volhynia in International Relations in $11^{\text {th }}-14^{\text {th }}$ c., Kraków 2012.

Терський С., Лучеськ X-XV ст., Львів 2006.

\section{The royal document of armistice with Švitrigaila of 20 August 1431}

\section{Summary}

The main purpose of this paper is to publish the document, so far unedited in its entirety, of the so-called Armistice of Łuck, dated 20 August 1431 and issued by King Władysław Jagiełło. Its guarantors were seventeen Polish barons, present with the king at the time. The truce was to last until 26 August and made it possible to complete the negotiations putting an end to the Polish-Lithuanian war in Volhynia (the so-called War of Łuck). As a result of the negotiations, another armistice document was issued in Czartorysk by Švitrigaila, Grand Duke of Lithuania (1 September 1431), and of another one a day later (2 September) by King Władysław Jagiełło. The so-called Armistice of Czartorysk made the truce last for over two years (until 24 June 1433). The document of Władysław Jagiełło of 20 August 1431 was presented to the other negotiating side and later housed in the archive of the Grand Duchy of Lithuania, where it remained until mid- $17^{\text {th }}$ century. After Vilnius was taken by Russians during the war with the Polish-Lithuanian 
Republic in 1655, the document was bequeathed to the archive of the Ambassadorial Prikaz (the office in charge of foreign affairs). Now it is housed in Russian State Archive of Historical Records (RGADA) in Moscow. The list of guarantors of the Łuck Armistice document widens the knowledge of Władysław Jagiełło's companions during the war of the summer of 1431. It was also possible to identify some other, so far unknown, Polish participants of the military activities near Łuck. The identification of high officials close to the king sheds new light on the decision making process, in the result of which the armistice was forged. A large number of royal advisors near Łuck originated from Great Poland. 


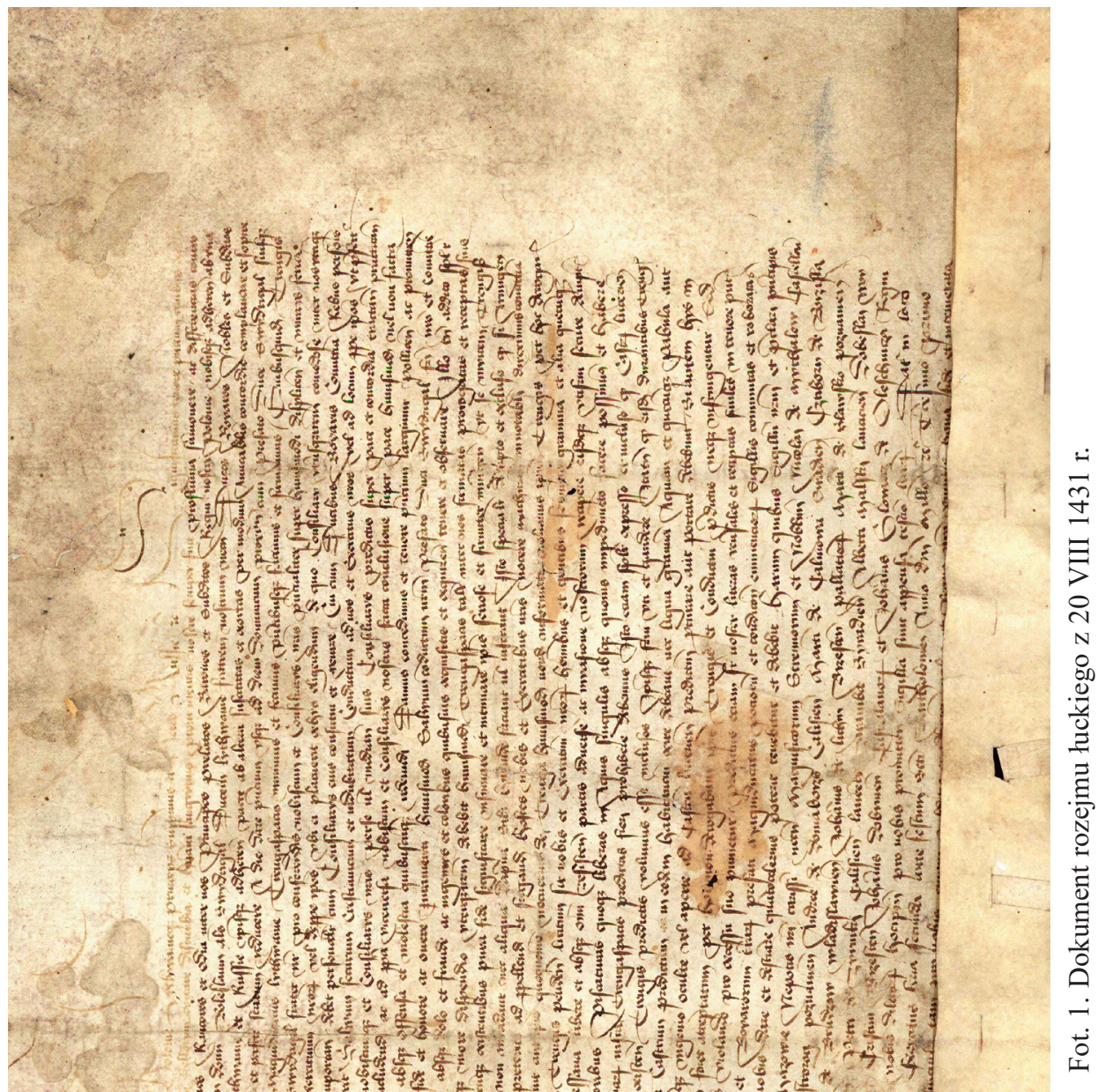

0.

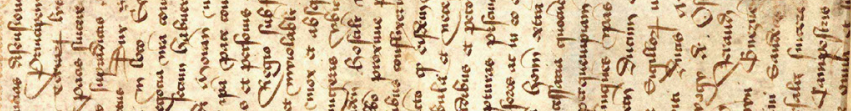

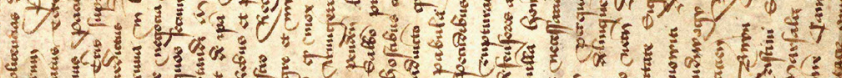

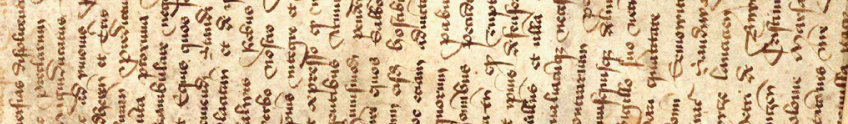

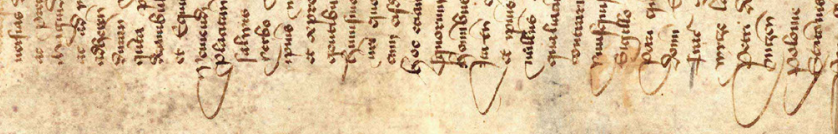




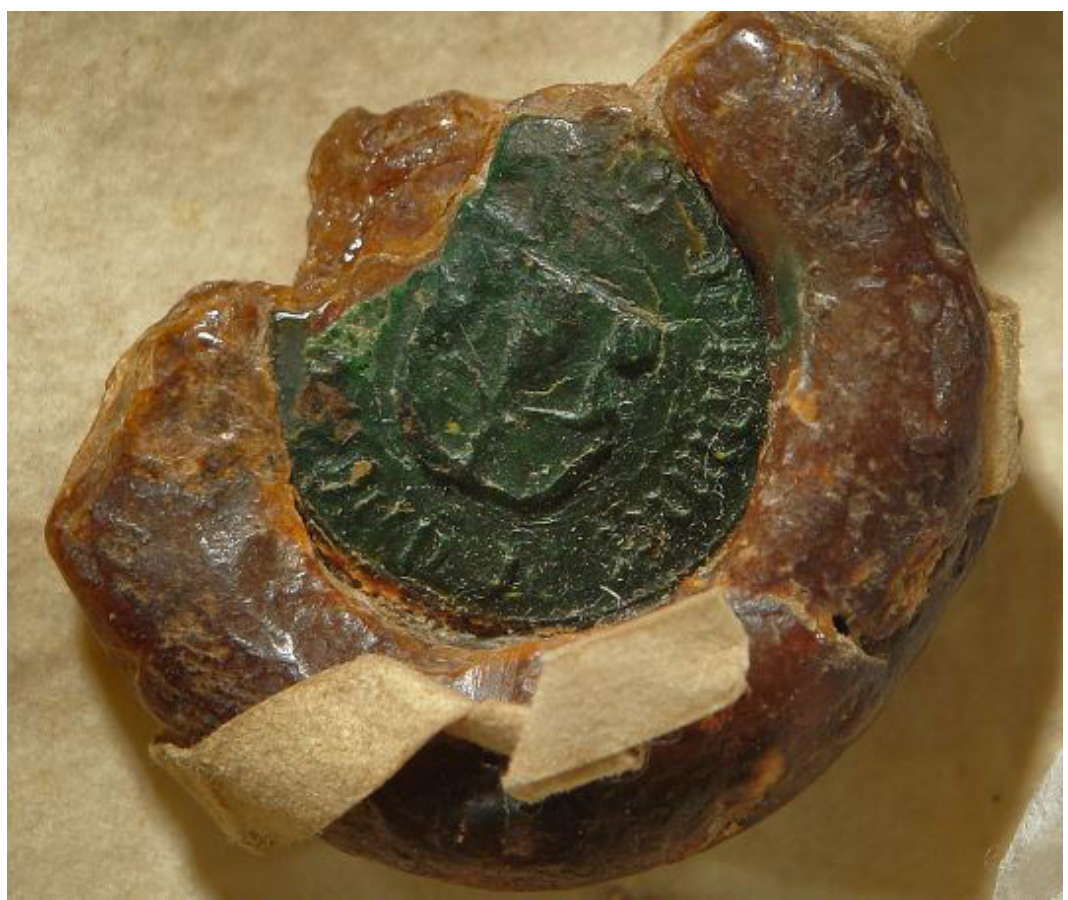

Fot. 2. Pieczęć wojewody brzeskiego Jana z Lichenia

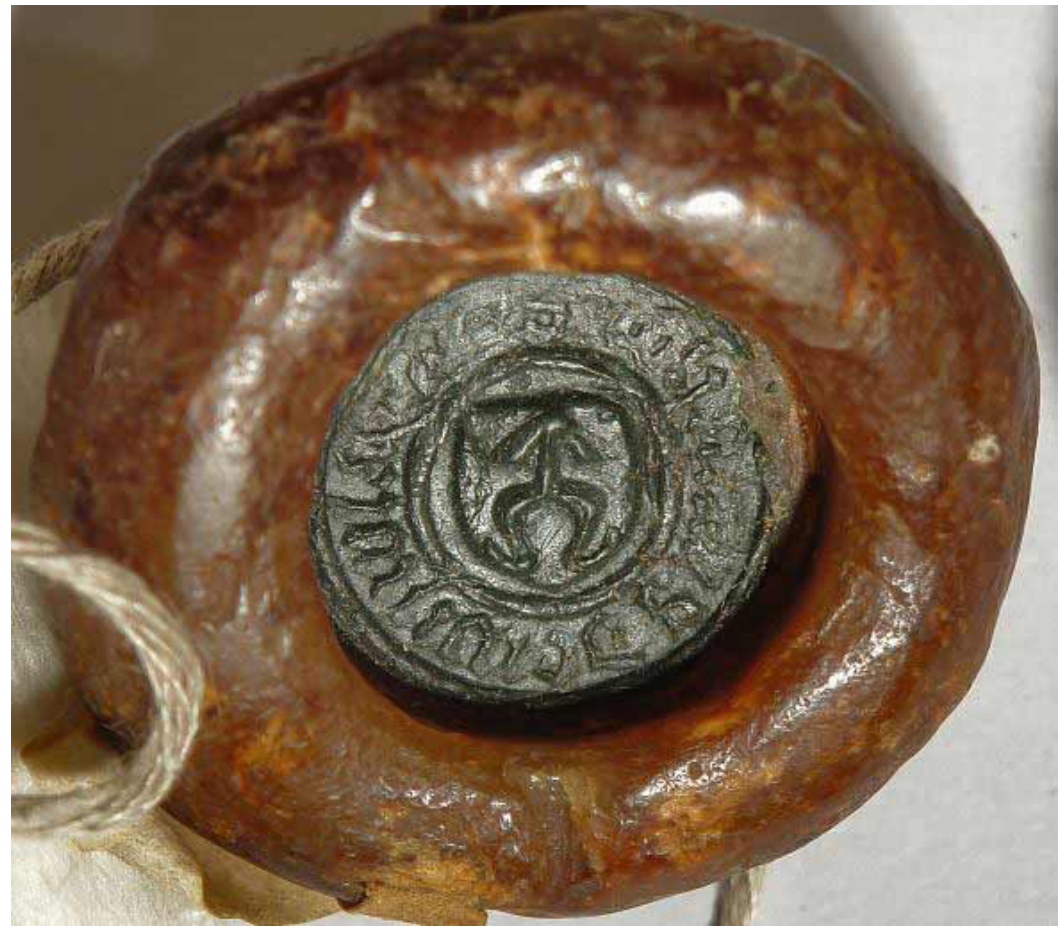

Fot. 3. Pieczęć niezidentyfikowanego dysponenta herbu Odrowąż 


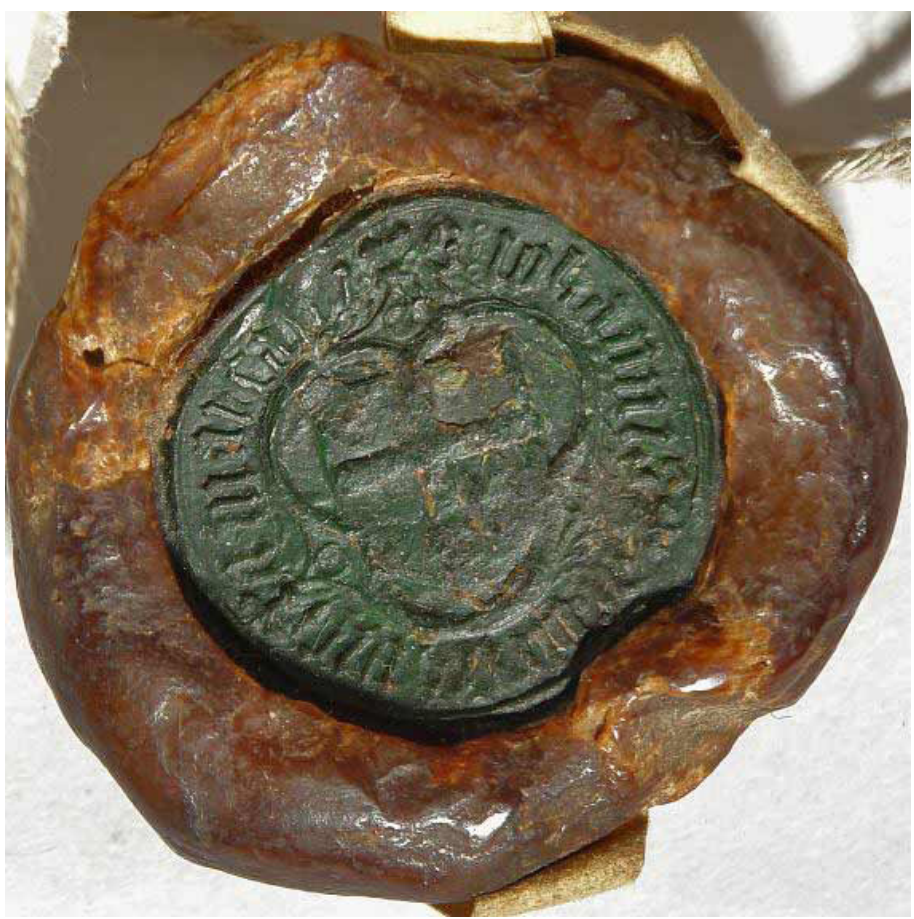

Fot. 4. Pieczęć marszałka Królestwa Polskiego Jana Głowacza z Oleśnicy

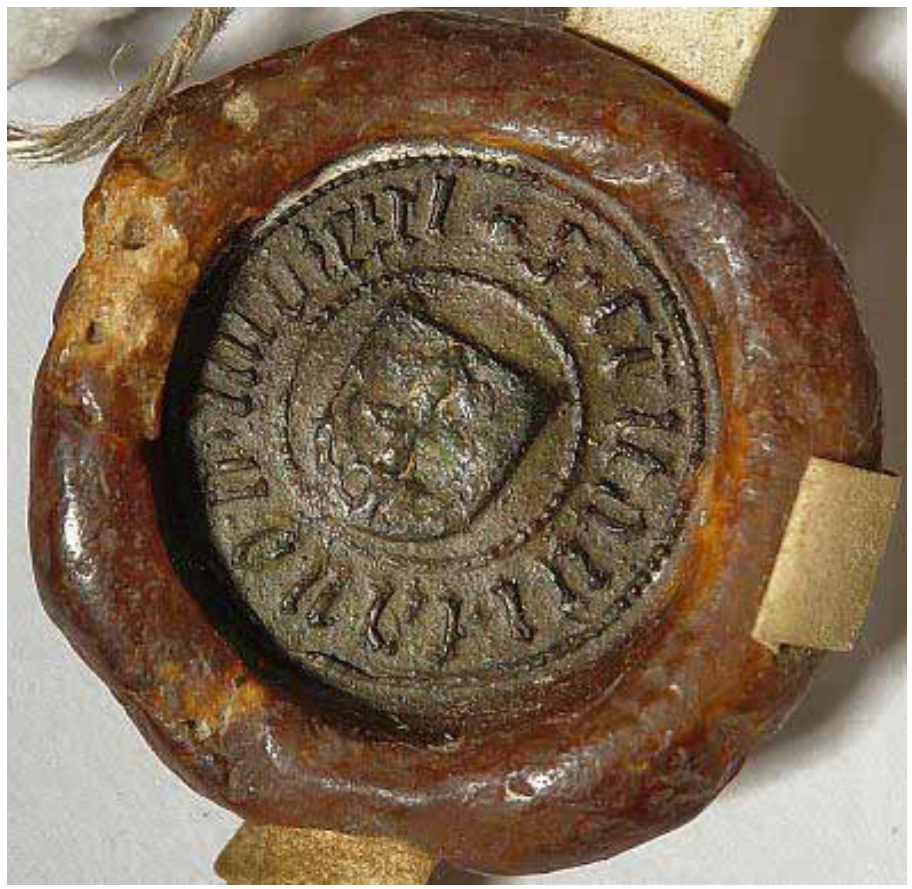

Fot. 5. Pieczęć kasztelana sądeckiego Krystyna z Koziegłów 


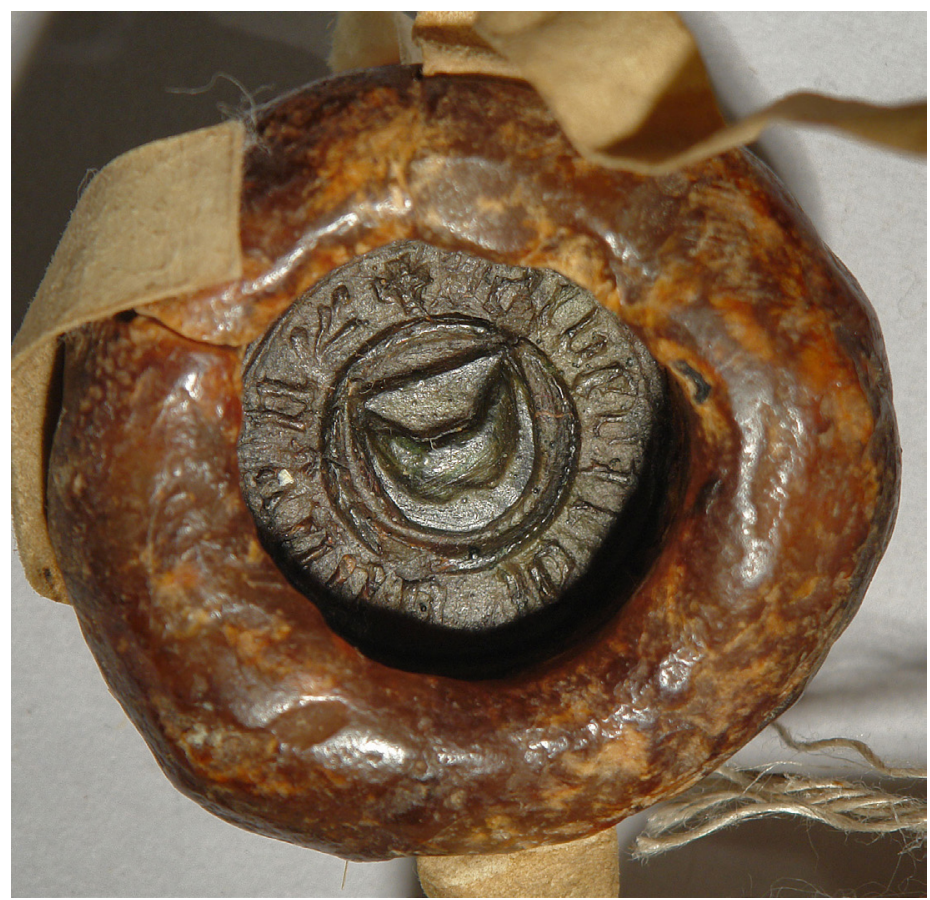

Fot. 6. Pieczęć przywieszona przez kasztelana gnieźnieńskiego Piotra z Bnina 